\title{
Stable isotopic composition of perchlorate and nitrate accumulated in plants: hydroponic experiments and field data
}

Nubia Luz Estrada ${ }^{a}$, J.K. Böhlke ${ }^{b}$, Neil C. Sturchio ${ }^{c}$, Baohua Gu ${ }^{\mathrm{d}}$, Greg Harvey ${ }^{\mathrm{e}}$, Kent O. Burkey ${ }^{\mathrm{f}}$, David A. Grantz ${ }^{\mathrm{g}}$, Margaret T. McGrath ${ }^{\mathrm{h}}$, Todd A. Anderson', Balaji Rao ${ }^{\mathrm{a}}$, Ritesh Sevanthi ${ }^{\mathrm{a}}$, Paul B. Hatzinger ${ }^{\mathrm{j}}$, W. Andrew Jackson*, a

a Department of Civil, Environmental, and Construction Engineering, Texas Tech University, Lubbock, Texas, 79409-1023 USA

${ }^{\mathrm{b}}$ National Research Program, U.S. Geological Survey, Reston, VA 20192, USA

${ }^{\mathrm{c}}$ Department of Geological Sciences, University of Delaware, Newark, DE 19716, USA

${ }^{\mathrm{d}}$ Environmental Sciences Division, Oak Ridge National Laboratory, Oak Ridge, TN, USA

${ }^{\mathrm{e}}$ U.S. Air Force, ASC/ENVR, Wright-Patterson AFB, Ohio, 45433, USA

${ }^{\mathrm{f}}$ U.S.D.A.-A.R.S., Plant Sciences Research Unit, North Carolina State University, Raleigh, NC 27607, USA

${ }^{\mathrm{g}}$ Department of Botany and Plant Sciences, University of California, Riverside, Kearney Agricultural Center, Parlier, CA 93648, USA

${ }^{\mathrm{h}}$ Plant Pathology \& Plant-Microbe Biology Section, SIPS, Cornell University, Long Island Horticultural Research and Extension Center, Riverhead, NY 11901, USA

${ }^{\mathrm{i}}$ Department of Environmental Toxicology, The Institute of Environmental and Human Health (TIEHH), Lubbock, Texas 79409-1163, USA

${ }^{j}$ CB\&I Federal Services, Lawrenceville, NJ 08648, USA

*Corresponding Author. E-mail: andrew.jackson@ttu.edu. Phone: (806) 834-6575

\begin{abstract}
Natural perchlorate $\left(\mathrm{ClO}_{4}^{-}\right)$in soil and groundwater exhibits a wide range in stable isotopic compositions $\left(\delta^{37} \mathrm{Cl}, \delta^{18} \mathrm{O}\right.$, and $\left.\Delta^{17} \mathrm{O}\right)$, indicating that $\mathrm{ClO}_{4}{ }^{-}$may be formed through more than one pathway and/or undergoes post-depositional isotopic alteration. Plants are known to accumulate $\mathrm{ClO}_{4}{ }^{-}$, but little is known about their ability to alter its isotopic composition. We examined the potential for plants to alter the isotopic composition of $\mathrm{ClO}_{4}{ }^{-}$in hydroponic and field experiments conducted with snap beans (Phaseolus vulgaris L.). In hydroponic studies, anion ratios indicated that $\mathrm{ClO}_{4}{ }^{-}$was transported from solutions into plants similarly to $\mathrm{NO}_{3}{ }^{-}$but preferentially to $\mathrm{Cl}^{-}(\sim 4 \mathrm{X})$. The $\mathrm{ClO}_{4}{ }^{-}$isotopic compositions of initial $\mathrm{ClO}_{4}{ }^{-}$reagents, final growth solutions, and aqueous extracts from plant tissues were essentially indistinguishable, indicating no significant isotope effects during $\mathrm{ClO}_{4}{ }^{-}$uptake or accumulation. The $\mathrm{ClO}_{4}{ }^{-}$isotopic
\end{abstract}


composition of field-grown snap beans was also consistent with that of $\mathrm{ClO}_{4}{ }^{-}$in varying proportions from irrigation water and precipitation. $\mathrm{NO}_{3}{ }^{-}$uptake had little or no effect on $\mathrm{NO}_{3}{ }^{-}$ isotopic compositions in hydroponic solutions. However, a large fractionation effect with an apparent $\varepsilon\left({ }^{15} \mathrm{~N} /{ }^{18} \mathrm{O}\right)$ ratio of 1.05 was observed between $\mathrm{NO}_{3}{ }^{-}$in hydroponic solutions and leaf extracts, consistent with partial $\mathrm{NO}_{3}{ }^{-}$reduction during assimilation within plant tissue. We also explored the feasibility of evaluating sources of $\mathrm{ClO}_{4}^{-}$in commercial produce, as illustrated by spinach, for which the $\mathrm{ClO}_{4}{ }^{-}$isotopic composition was similar to that of indigenous natural $\mathrm{ClO}_{4}{ }^{-}$

. Our results indicate that some types of plants can accumulate and (presumably) release $\mathrm{ClO}_{4}{ }^{-}$ to soil and groundwater without altering its isotopic characteristics. Concentrations and isotopic compositions of $\mathrm{ClO}_{4}{ }^{-}$and $\mathrm{NO}_{3}{ }^{-}$in plants may be useful for determining sources of fertilizers and sources of $\mathrm{ClO}_{4}{ }^{-}$in their growth environments and consequently in food supplies.

\section{Keywords}

Oxygen isotopes; Chlorine isotopes; Nitrogen isotopes; Plant uptake; Isotope fractionation in snap beans (Phaseolus vulgaris L.); Irrigation

\section{Introduction}

Perchlorate $\left(\mathrm{ClO}_{4}^{-}\right)$is a ubiquitous trace inorganic constituent in the environment with both natural and anthropogenic sources. Widespread occurrence of natural $\mathrm{ClO}_{4}{ }^{-}$has been documented and there are numerous anthropogenic sources of $\mathrm{ClO}_{4}{ }^{-}$(Rajagopalan et al., 2009; Rao et al., 2007; Kounaves et al., 2010; Böhlke et al., 2009; Jackson et al., 2015). Because of its potential impact on thyroid function, the U.S. Environmental Protection Agency (EPA) is currently in the process of establishing a maximum contaminant level (MCL) for $\mathrm{ClO}_{4}{ }^{-}$in drinking water (Greer et al., 2002; “Drinking Water," 2011). Leafy edible plants (e.g. lettuce and spinach), fruits and vegetables, and forage species are also an exposure route for humans, either from direct ingestion or when used for dairy feed that can lead to elevated concentrations of 
$\mathrm{ClO}_{4}{ }^{-}$in human breast milk and animal milk (Dasgupta et al., 2006; Jackson et al., 2005; Kirk et al., 2003; 2007; Sanchez et al., 2005).

Differentiating between various sources of $\mathrm{ClO}_{4}{ }^{-}$is possible based on the stable isotopic composition of $\mathrm{ClO}_{4}{ }^{-}$. The $\mathrm{Cl}$ and $\mathrm{O}$ stable isotopic composition of $\mathrm{ClO}_{4}{ }^{-}$has been shown to vary among samples representing different major sources or geographic areas (Jackson et al., 2010; Sturchio et al., 2011). Natural $\mathrm{ClO}_{4}{ }^{-}$has variable but generally positive $\Delta^{17} \mathrm{O}$ values reflecting formation reactions involving ozone $\left(\mathrm{O}_{3}\right)$ and is thought to be derived largely from atmospheric deposition (Jackson et al., 2010; Sturchio et al., 2011). However, isotopic variation of natural $\mathrm{ClO}_{4}{ }^{-}$indicates that multiple production mechanisms may exist, or that postdepositional alteration (fractionation and/or exchange) can alter the original isotopic composition. Processes that could alter $\mathrm{ClO}_{4}{ }^{-}$isotopic compositions in the environment include microbial transformation, diffusion, isotope exchange with water, and plant uptake/transformation (Jackson et al., 2010; Van Aken and Schnoor, 2002; Sturchio et al., 2007; Hatzinger et al., 2009).

Microbial degradation produces a well-described mass-dependent effect on $\delta^{37} \mathrm{Cl}$ and $\delta^{18} \mathrm{O}$, but degradation alone cannot explain the isotopic variation among different geographic locations (Sturchio et al., 2007; Hatzinger et al., 2009; Sturchio et al., 2003). Isotopic fractionation of $\mathrm{ClO}_{4}{ }^{-}$by transport-related processes (dissolution/precipitation and diffusion) has not been thoroughly investigated, but such effects are likely to be smaller than the observed isotopic variations of natural $\mathrm{ClO}_{4}{ }^{-}$(Desaulniers et al., 1986; Kaufmann et al., 1993; Ransom et al., 1995). Isotope exchange of $\mathrm{O}$ between $\mathrm{ClO}_{4}{ }^{-}$and coexisting substances, such as water, could affect $\mathrm{ClO}_{4}{ }^{-}$isotopic composition, but experiments indicate the $\mathrm{ClO}_{4}{ }^{-}-\mathrm{H}_{2} \mathrm{O}$ exchange half-life is greater than 100 years in the absence of catalysts (Böhlke et al. 2005; Hoering et al., 1958). 
The effect of plant uptake on $\mathrm{ClO}_{4}{ }^{-}$isotopic compositions is not yet clear. Numerous soil and hydroponic exposure experiments (Sanchez et al., 2005; Seyfferth and Parker, 2007; Seyfferth et al., 2008 ab; Ha et al., 2011; Voogt and Jackson, 2010) have indicated the potential for plants to uptake and accumulate $\mathrm{ClO}_{4}{ }^{-}$. It is possible that plants could change the $\mathrm{ClO}_{4}{ }^{-}$ isotopic composition through a variety of mechanisms including: transport carriers in the root; diffusion limitations through the root; reduction of $\mathrm{ClO}_{4}{ }^{-}$within the plant; translocation within the plant; and exchange of $\mathrm{O}$ between $\mathrm{ClO}_{4}{ }^{-}$and $\mathrm{H}_{2} \mathrm{O}$ or other compounds catalyzed by plant enzymes. It is well-known that physiological and physicochemical processes (fixation, assimilation, and diffusion) in plants can cause isotopic fractionation of carbon (Marshall et al., 2007; Farquhar et al., 1989; Schmidt et al., 2015) $\left({ }^{13} \mathrm{C} /{ }^{12} \mathrm{C}\right)$ and nitrogen $\left({ }^{15} \mathrm{~N} /{ }^{14} \mathrm{~N}\right)($ Schmidt et al., 2015; Evans, 2001; Mariotti et al., 1981; Werner and Schmidt, 2002); likewise, intracellular processing of $\mathrm{ClO}_{4}{ }^{-}$within plants may also affect $\mathrm{ClO}_{4}{ }^{-}$isotopic compositions. There are conflicting published results concerning $\mathrm{ClO}_{4}{ }^{-}$reduction in plants (Van Aken and Schnoor, 2002; Seyfferth et al., 2008b). Understanding whether or not plants can alter the isotopic composition of $\mathrm{ClO}_{4}{ }^{-}$is important because such alteration could introduce complications for determining sources of $\mathrm{ClO}_{4}{ }^{-}$in plants, soils, and groundwaters.

In the current study, controlled experiments were conducted to develop procedures for analyzing the isotopic composition of $\mathrm{ClO}_{4}{ }^{-}$extracted from plants and to determine whether isotopic exchange or fractionation (by transport or degradation) might alter the isotopic composition of $\mathrm{ClO}_{4}{ }^{-}$accumulating in plants. This was accomplished by comparing the stable isotopic compositions of $\mathrm{ClO}_{4}{ }^{-}$accumulated in hydroponically grown snap bean plants (Phaseolus vulgaris L.) with those of the starting reference materials and growth solutions. Results were interpreted in part by contrasting the isotopic fractionation of $\mathrm{ClO}_{4}{ }^{-}$and $\mathrm{NO}_{3}{ }^{-}$in the 
same experiments. This is important because isotopic fractionation effects of enzymatic reactions may not fully be expressed in residual reactants (i.e. in heterogeneous systems where reactions are transport-limited). Therefore, a lack of observable isotope effects in extractable $\mathrm{ClO}_{4}{ }^{-}$might not be a reliable indicator of $\mathrm{ClO}_{4}{ }^{-}$stability unless extractable $\mathrm{NO}_{3}{ }^{-}$exhibited substantial fractionation effects. We also evaluated $\mathrm{ClO}_{4}{ }^{-}$isotopic composition in plants and source water for field-grown snap beans to validate the applicability of our methods in a more realistic setting. In order to demonstrate how our methods can be used to identify sources of $\mathrm{ClO}_{4}^{-}$in the food chain, we analyzed commercially grown spinach and snap bean plants exposed only to background concentrations of $\mathrm{ClO}_{4^{-}}$.

\section{Materials and Methods}

\subsection{Hydroponic Snap Bean Studies}

Hydroponic greenhouse studies were conducted at the Texas Tech University Greenhouse Complex in Lubbock, TX. Snap beans (Phaseolus vulgaris L.) were grown hydroponically in a nutrient solution containing commercial $\mathrm{ClO}_{4}{ }^{-}$and/or a USGS $\mathrm{ClO}_{4}{ }^{-}$standard. Snap beans were selected for the hydroponic study as part of more comprehensive ongoing growth studies by the Agricultural Research Service (ARS) of the U.S. Department of Agriculture (USDA), which are described in the snap bean field studies section below. Details regarding the growth, collection, and analysis of the snap bean plants in the hydroponic study are described below.

Two hydroponic experiments were conducted with multiple treatments in each experiment (Table 1). Treatments generally consisted of snap beans (Phaseolus vulgaris L.) grown in nutrient solutions containing $\mathrm{ClO}_{4}^{-}(0.01,2$, and $10 \mathrm{mg} / \mathrm{L})$ along with $\mathrm{NO}_{3}^{-}(235-274$ mg NO3-- $/ / \mathrm{L}$ ). The 2 and $10 \mathrm{mg} / \mathrm{L} \mathrm{ClO}_{4}{ }^{-}$treatments were used in order to reduce the amount of plant mass needed to be extracted for isotopic analysis while the $0.01 \mathrm{mg} / \mathrm{L} \mathrm{ClO}_{4}{ }^{-}$treatment was used to approximate realistic values of $\mathrm{ClO}_{4}{ }^{-}$observed in nature (Rajagopalan et al., 2009; Rao et 
al., 2007) and to compare the relative differences in uptake between low and high concentrations of source $\mathrm{ClO}_{4}^{-}$. Two control treatments were also evaluated. One control contained no plants and $1 \mathrm{mg} / \mathrm{L} \mathrm{ClO}_{4}{ }^{-}$and the other contained plants and no $\mathrm{ClO}_{4}{ }^{-}$. To minimize ambiguity in the results, two sources of $\mathrm{ClO}_{4}^{-}$were used in the experiments.

The $\mathrm{ClO}_{4}{ }^{-}$for the $0.01,1$, and $10 \mathrm{mg} / \mathrm{L}$ exposures was supplied using a synthetic $98 \%$ sodium perchlorate $\left(\mathrm{NaClO}_{4}\right)$ lab reagent (ACROS Organics) with normal synthetic isotopic composition, while the $\mathrm{ClO}_{4}{ }^{-}$used in the $2 \mathrm{mg} / \mathrm{L}$ exposure was a potassium perchlorate $\left(\mathrm{KClO}_{4}\right)$ reagent (RSIL5) that had anomalously low $\delta^{37} \mathrm{Cl}$, high $\delta^{18} \mathrm{O}$, and large non-mass-dependent ${ }^{17} \mathrm{O}$ anomaly (Böhlke et al., 2017). These contrasting initial isotopic compositions enabled distinctions to be made between isotopic fractionation, exchange, and mixing.

Snap bean seeds were sown in small rockwool cubes presoaked in reverse osmosis (RO) water. The seeds were watered daily with RO water until full germination (presence of 4-5 leaves, $\sim 3$ weeks). During the germination period, the small rockwool cubes were transferred to larger rockwool cubes. Polypropylene/polyethylene opaque tubs $(52.7 \mathrm{~cm} \times 36.87 \mathrm{~cm} \times 33.3 \mathrm{~cm})$ were pre-rinsed with RO water three times and were filled with $32 \mathrm{~L}$ and $34 \mathrm{~L}$ (for experiment 1 and experiment 2, respectively) of a standard nutrient solution (Voogt and Jackson, 2010) with minor modifications. Prior to transfer of the plants to the growth tubs, the $\mathrm{pH}$ of the nutrient solution was adjusted to between 5.5 and 6.1 by addition of $\mathrm{HNO}_{3}$. The rockwool cubes containing plants were then positioned on the lids of the tubs, with the plant roots suspended into the nutrient solution and plant shoots exposed to air. Rockwool cubes were covered with aluminum foil to prevent algae growth. Commercial aquarium pumps supplied air to maintain bulk oxic conditions in solution for the duration of the experiments. 
After germination reached the 4-5 leaf stage ( 15-18 days), plants were exposed to $\mathrm{ClO}_{4}{ }^{-}$ by addition of a concentrated solution in selected tubs. The water level in each tub was maintained by adding RO water weekly. Growth solution samples from each tub were collected every two to three days and refrigerated immediately until analyzed. Electrical conductivity and $\mathrm{pH}$ were also measured two to three times weekly. $\mathrm{pH}$ was maintained between 5.5 and 6.1 using 3M KOH. After a few weeks, insects became apparent and leaves were treated using Safer Soap (AgroCrop Sciences) or Orthonex (an organophosphate insecticide).

Snap bean plants were harvested 62-65 days after germination, corresponding to 38 days of $\mathrm{ClO}_{4}{ }^{-}$exposure. The bean pods, leaves, stems, and roots from each treatment were separated, weighed, and frozen until processed. All treatments were evaluated to determine the amount of $\mathrm{ClO}_{4}{ }^{-}$and $\mathrm{NO}_{3}{ }^{-}$lost from solution over time and accumulated in plant tissue, while a subset of treatments $\left(1 \mathrm{mg} / \mathrm{L}\right.$ no plants control, $2 \mathrm{mg} / \mathrm{L}$, and $\left.10 \mathrm{mg} / \mathrm{L} \mathrm{ClO}_{4}{ }^{-}\right)$were evaluated for stable isotopes.

The plant-solute extraction method of Ellington and Evans (2000) was used in these experiments with minor modifications. The total mass of leaves collected per replicate $(\sim 85-$ $400 \mathrm{~g}$ ) in each treatment was extracted in $20 \mathrm{~g}$ fresh weight $(\mathrm{FW})$ portions. The bean pods, stems, and roots were separated into approximately 5, 6, and $10 \mathrm{~g} \mathrm{FW}$ portions, respectively. Each portion of leaves, bean pods, stems, and roots were placed in containers (vials) with 200, 25, 25, and $20 \mathrm{~mL}$ of distilled deionized (DDI) water, respectively. Water/plant tissue mixtures were boiled for 30-60 minutes in a precision boiler set at $99^{\circ} \mathrm{C}$. The boiled extracts were centrifuged and the supernatant was decanted into containers (vials) with activated alumina $\left(\mathrm{Al}_{2} \mathrm{O}_{3}\right)$ and placed in the refrigerator overnight to remove organics. Each leaf aqueous extract was then vacuum filtered using GF/F $47 \mathrm{~mm}$ Whatman $^{\mathrm{TM}}$ filters. The bean pods, stem, and root 
extracts were filtered using syringe Whatman ${ }^{\mathrm{TM}}$ filters. From each tissue extraction solution, a small volume was separated and cleaned by passing the aqueous extract through a $(0.2 \mu \mathrm{m})$ syringe filter and a Dionex OnGuard ${ }^{\circledR}$ RP cartridge to further remove organic substances. Cleaned samples from each treatment were analyzed for $\mathrm{ClO}_{4}{ }^{-}, \mathrm{Cl}^{-}, \mathrm{NO}_{3}{ }^{-} \mathrm{N}, \mathrm{SO}_{4}{ }^{2-}$, and $\mathrm{PO}_{4}{ }^{3-}$, and a small volume was set aside and preserved for $\mathrm{NO}_{3}{ }^{-}$isotopic analysis by raising the $\mathrm{pH}$ to 11-12 using 50\% w/w NaOH. The remaining filtered supernatants of all leaf extractions per replicate were pooled together to make one extraction solution per replicate treatment for $\mathrm{ClO}_{4}{ }^{-}$ isotopic analysis. The pooled leaf extracts for each replicate treatment as well as the remaining nutrient solutions of each replicate treatment, excluding the $0.01 \mathrm{mg} / \mathrm{L}$ and no $\mathrm{ClO}_{4}{ }^{-}$control plant extraction and growth solutions, were pumped through Purolite $®$ A-530E resin columns to capture $\mathrm{ClO}_{4}^{-}$(Böhlke et al., 2017; Hatzinger et al., 2011). Columns were preserved with $0.1 \mathrm{~N}$ $\mathrm{HCl}(\mathrm{pH} \leq 2)$ and stored at $4^{\circ} \mathrm{C}$ until processing.

\subsection{Snap Bean Field Studies}

Ozone-sensitive (S156) and ozone-tolerant (R123) snap bean genotypes described previously (Burkey et al., 2005) were grown in field plots during the summers of 2009-2011 at two locations to provide bulk leaf tissue for extraction and isotopic analysis of $\mathrm{ClO}_{4}{ }^{-}$. The first site was located at the USDA-ARS Air Quality field site $5 \mathrm{~km}$ south of Raleigh, NC (Lat: 35 $43^{\circ} 59^{\prime \prime} \mathrm{N}$; Long: $78^{\circ} 41^{\prime} 2^{\prime \prime} \mathrm{W}$ ) and the second site was located at the Long Island Horticultural Research \& Extension Center, Riverhead, NY (Lat: 4057'36" N; Long: 7243'12" W). For each location in each year, three separate plots consisting of 500 linear feet of row were established as three experimental blocks with each block consisting of one S156 plot and one R123 plot (randomized complete block design). Fields were cultivated before planting and a ' $10-10-10$ Extra' fertilizer blend (Carolina Eastern-Vail, Niverville, NY), with an average $\mathrm{ClO}_{4}{ }^{-}$ 
concentration of less than $45 \mu \mathrm{g} / \mathrm{kg}$-dry weight, was applied at a rate of $500 \mathrm{lbs} / \mathrm{acre}(0.056$

$\mathrm{kg} / \mathrm{m}^{2}$ ) by broadcast and incorporated into the soil prior to planting. Approximately 1500 seeds were sown per plot in late May or early June each year at both sites. Plots were provided with water equivalent to at least 1 inch of rain per week by either natural rainfall or supplemental drip irrigation from wells located at each site. In preliminary tests, well water at the Raleigh, NC site was found to contain concentrations of $\mathrm{ClO}_{4}{ }^{-}$up to $5 \mu \mathrm{g} / \mathrm{L}$ in excess of typical background concentrations ( $<0.005-1 \mu \mathrm{g} / \mathrm{L})$ (Rajagopalan et al., 2009; Rao et al., 2007). In this case, a Purolite ${ }^{\circledR} \mathrm{A}-530 \mathrm{E}$ ion exchange resin column was used to reduce $\mathrm{ClO}_{4}{ }^{-}$concentration for irrigation to within typical background values. Irrigation water at the NY site was found to contain $\sim 0.3 \mu \mathrm{g} / \mathrm{L} \mathrm{ClO}_{4}{ }^{-}$so no resin column was used. At 45-55 days after planting at the developmental stage, when vegetative biomass was near maximum, leaf tissue was manually harvested from each plot, placed in mesh bags, and dried at $60^{\circ} \mathrm{C}$. Dried leaf tissue was stored in large plastic bags to exclude moisture and prevent contamination and then shipped to Texas Tech University for $\mathrm{ClO}_{4}^{-}$extraction and purification.

Field grown snap bean leaves were extracted in bulk two times for 48 hours in large 55gallon barrels using reverse osmosis water to which the $\mathrm{pH}$ was reduced to 2 using $\mathrm{HCl}$. Leaves were removed from solution and the solution was pumped through a $0.45 \mu \mathrm{m}$ filter and Purolite ${ }^{\circledR}$ A-530E resin columns. The resin columns were stored at $4^{\circ} \mathrm{C}$ until processed for $\mathrm{ClO}_{4}{ }^{-}$isotopes.

\subsection{Commercial Spinach Sample}

Fresh spinach leaves (38 kg) in pre-packaged plastic bags were purchased from a supermarket in Lubbock, TX in early November, 2012. Spinach sold by the supplier was conventionally grown by contract farms in the Salinas Valley, CA region from April through 
October and the Yuma, AZ region from November through March. No other information about growth conditions for this product are available.

Perchlorate was extracted from spinach using the same extraction procedure as the field grown snap bean leaves. Leaves were removed from solutions and the extraction solution was pumped through a $0.45 \mu \mathrm{m}$ filter and Purolite ${ }^{\circledR}$ A-530E resin column. The extraction column was stored at $4^{\circ} \mathrm{C}$ until processed for $\mathrm{ClO}_{4}{ }^{-}$isotopes.

\subsection{Anion Concentration Measurements}

Concentrations of $\mathrm{ClO}_{4}{ }^{-}$and major anions $\left(\mathrm{Cl}^{-}, \mathrm{NO}_{3}{ }^{-}, \mathrm{SO}_{4}{ }^{2-}, \mathrm{PO}_{4}{ }^{3-}\right)$ in hydroponic solutions and plant extracts were measured at Texas Tech University using sequential ion chromatography-mass spectroscopy-mass spectroscopy (IC-MS/MS) with a reporting limit of $0.05 \mu \mathrm{g} / \mathrm{L}\left(\mathrm{ClO}_{4}^{-}\right)$and ion chromatography (EPA Method 300.0) with a reporting limit of 0.5 $\mathrm{mg} / \mathrm{L}$ (other anions) as described in Rao et al. (2007). To facilitate comparisons of measured concentrations, plant bioconcentration factors $(\mathrm{BCF})$ were calculated according to Equation 1 (Newman and Clements, 2008).

$$
\begin{aligned}
& \operatorname{BCF}\left(\frac{L}{\mathrm{~kg}}\right) \\
= & \frac{\text { Ion concentration in plant tissue }(\text { fresh weight, } F W) \text { at harvest }(\mathrm{mg} / \mathrm{kg})}{\text { Initial ion concentration in growth solution }(\mathrm{mg} / \mathrm{L})}
\end{aligned}
$$

\subsection{Perchlorate Purification}

The $\mathrm{ClO}_{4}{ }^{-}$in the Purolite ${ }^{\circledR}$ A530E resin columns was extracted and purified at Oak Ridge National Laboratory using procedures described previously (Hatzinger et al., 2011; Böhlke et al., 2017). The extraction process consisted of removing the adsorbed $\mathrm{ClO}_{4}{ }^{-}$from the resin in the Purolite ${ }^{\circledR}$ A530E column, rinsing it with ultra-pure DDI water, transferring it into a preparative glass chromatography column (100 $\mathrm{mL}$ volume), and then washing it with 
approximately 5 bed volumes of $4 \mathrm{M} \mathrm{HCl}$ to remove impurities (i.e. $\mathrm{NO}_{3}{ }^{-}$, organics, carbonates) (Hatzinger et al., 2011; Böhlke et al., 2017). The $\mathrm{ClO}_{4}{ }^{-}$was eluted from the preparative glass column with a mixed solution of $1 \mathrm{M} \mathrm{FeCl}_{3}$ and $4 \mathrm{M} \mathrm{HCl}$. The $\mathrm{FeCl}_{3}-\mathrm{HCl}$ eluent solution (containing the eluted $\mathrm{ClO}_{4}^{-}$) was neutralized with $\mathrm{NaOH}(\mathrm{pH} \sim 9-10)$ to precipitate out $\mathrm{Fe}$ as $\mathrm{Fe}(\mathrm{OH})_{3}$ (Hatzinger et al., 2011; Böhlke et al., 2017). After removing $\mathrm{Fe}(\mathrm{OH})_{3}$ precipitates by centrifugation, the supernatant solution was collected and evaporated using a vacuum concentration system until the $\mathrm{ClO}_{4}{ }^{-}$concentration in solution was in excess of $3 \mathrm{mg} / \mathrm{mL}$ (Hatzinger et al., 2011; Böhlke et al., 2017). After removing salts (or $\mathrm{NaCl}$ precipitates during evaporation), the $\mathrm{ClO}_{4}{ }^{-}$in the remaining solution was crystallized as cesium perchlorate $\left(\mathrm{CsClO}_{4}\right)$ by adding $\mathrm{CsCl}$ (Hatzinger et al., 2011; Böhlke et al., 2017).

\subsection{Isotopic Ratio Analyses}

Stable isotope ratios of $\mathrm{O}$ and $\mathrm{N}$ in $\mathrm{ClO}_{4}{ }^{-}$and $\mathrm{NO}_{3}{ }^{-}\left(\delta^{18} \mathrm{O}, \delta^{17} \mathrm{O}, \Delta^{17} \mathrm{O}\right.$, and $\left.\delta^{15} \mathrm{~N}\right)$ in hydroponic solutions and plant extracts were analyzed at the Reston Stable Isotope Laboratory of the U.S. Geological Survey in Reston, VA (Sigman et al., 2001; Casciotti et al., 2002; Hatzinger et al., 2011; Böhlke et al., 2017); Selected samples were analyzed for $\mathrm{NO}_{2}{ }^{-}$concentration and isotopic composition, as $\mathrm{NO}_{2}{ }^{-}$can interfere with $\mathrm{NO}_{3}{ }^{-}$isotopic analysis (Böhlke et al., 2007; Casciotti et al., 2007). Oxygen stable isotope ratio analyses of $\mathrm{ClO}_{4}{ }^{-}$were performed by hightemperature conversion of the purified $\mathrm{ClO}_{4}{ }^{-}$salt $\left(\mathrm{CsClO}_{4}\right)$ to $\mathrm{CO}$ that was analyzed in continuous-flow mode by isotope-ratio mass spectrometry (CO-CFIRMS) and by in vacuo decomposition of the $\mathrm{ClO}_{4}{ }^{-}$salt $\left(\mathrm{CsClO}_{4}\right)$ to $\mathrm{O}_{2}$ that was analyzed in dual-inlet mode by isotoperatio mass spectrometry (O2-DIIRMS) (Hatzinger et al., 2011; Böhlke et al., 2017). Chlorine isotope ratios $\left(\delta^{37} \mathrm{Cl}\right)$ of $\mathrm{ClO}_{4}^{-}$were analyzed at the Environmental Isotope Geochemistry Laboratory of the University of Illinois at Chicago by conversion of the $\mathrm{CsClO}_{4}$ salt to methyl 
chloride $\left(\mathrm{CH}_{3} \mathrm{Cl}\right)$ gas that was analyzed by isotope-ratio mass spectrometry (IRMS) (Hatzinger et al., 2011; Böhlke et al., 2017).

Relative isotope ratios of samples are reported in delta notation $(\delta)$, defined as deviations from the corresponding molar ratios $(\mathrm{R})$ in specified standards (std): $\delta^{\mathrm{i}} \mathrm{E}=\mathrm{R}_{\text {sample }} / \mathrm{R}_{\text {std }}-1$, in parts per thousand (\%). For $\delta^{18} \mathrm{O}, \mathrm{R}$ is ${ }^{18} \mathrm{O} /{ }^{16} \mathrm{O}$ and std is VSMOW; for $\delta^{17} \mathrm{O}, \mathrm{R}$ is ${ }^{17} \mathrm{O} /{ }^{16} \mathrm{O}$ and std is VSMOW; for $\delta^{15} \mathrm{~N}, \mathrm{R}$ is ${ }^{15} \mathrm{~N} /{ }^{14} \mathrm{~N}$ and std is atmospheric $\mathrm{N}_{2}$; for $\delta^{37} \mathrm{Cl}, \mathrm{R}$ is ${ }^{37} \mathrm{Cl} /{ }^{35} \mathrm{Cl}$ and std is SMOC. Non-mass-dependent relative excess abundances of ${ }^{17} \mathrm{O}$ are given as $\Delta^{17} \mathrm{O}$ values: $\Delta^{17} \mathrm{O}=\left(\delta^{17} \mathrm{O}+1\right) /\left(\delta^{18} \mathrm{O}+1\right)^{0.525}-1$, also in parts per thousand (\%o). Secondary isotopic reference materials and calibration values used for $\mathrm{ClO}_{4}{ }^{-}$and $\mathrm{NO}_{3}{ }^{-}$have been reported previously (Böhlke et al., 2009; Böhlke et al., 2017; Böhlke et al., 2003) and are given in the SI.

Estimates of the $\mathrm{N}$ and $\mathrm{O}$ isotopic fractionation effects $\left(\varepsilon^{15} \mathrm{~N}\right.$ and $\varepsilon^{18} \mathrm{O}$, respectively) imparted on $\mathrm{NO}_{3}{ }^{-}$were derived by fitting data to linear Rayleigh equations $2-3$, where $\mathrm{f} \approx\left[\mathrm{NO}_{3}{ }^{-}\right]$ / $\left[\mathrm{NO}_{3}{ }^{-}\right]_{\text {initial }}$ (Mariotti et al., 1981).

$\ln \left(\delta^{15} N+1\right)=\ln \left(\delta^{15} N_{\text {initial }}+1\right)+\varepsilon^{15} N \times \ln (f)$

$\ln \left(\delta^{18} O+1\right)=\ln \left(\delta^{18} O_{\text {initial }}+1\right)+\varepsilon^{18} O \times \ln (f)$

Regression of $\ln \left(\delta^{15} \mathrm{~N}+1\right)$ or $\ln \left(\delta^{18} \mathrm{O}+1\right)$ on $\ln (\mathrm{f})$ yields slopes of $\varepsilon^{15} \mathrm{~N}$ and $\varepsilon^{18} \mathrm{O}$, respectively (Mariotti et al., 1981). Regressions and associated statistical errors for isotope data and anion mass data were determined by using the regression wizard function of the Sigmaplot 11 Scientific Data Analysis and Graphing Software. Values of $\delta$ and $\varepsilon$ defined above are reported in parts per thousand (per mil, \%o).

\section{Results}

\subsection{Hydroponic Snap Bean Study}

\subsubsection{Changes in Hydroponic Growth Solutions}


Substantial water loss occurred in both hydroponic experiments and was mainly attributed to transpiration. The cumulative volume of growth solution lost in treatments with no plants was less than $10 \%$ of the initial volume compared to cumulative losses of $\sim 70$ to $230 \%$ of the initial volume in treatments with plants (SI Figure S1). Within each experiment, the volume of solution transpired by plant treatments was similar regardless of the presence or absence of $\mathrm{ClO}_{4}^{-}$, but the volume transpired in experiment 2 was approximately twice that of experiment 1 (SI Figure S1). Experiment 1 was conducted during the months of October and December and experiment 2 during the months of April and May when temperatures were higher, which may have contributed to higher transpiration in experiment 2. Individual tubs contained more plants in experiment 1 (Table 1), but plant mass was 2-4 fold higher in experiment 2, also contributing to greater transpiration in experiment 2 .

As in a previous study (Seyfferth and Parker, 2007) $\mathrm{ClO}_{4}{ }^{-}$mass in hydroponic solutions of treatments with plants decreased gradually over time in a non-linear fashion with a cumulative mass loss of $60-80 \%$ of the initial $\mathrm{ClO}_{4}{ }^{-}$solution mass (SI Figure S2). The fractional mass loss of $\mathrm{ClO}_{4}{ }^{-}$from solution was independent of initial $\mathrm{ClO}_{4}{ }_{4}^{-}$concentration, but there was a larger overall decrease in $\mathrm{ClO}_{4}{ }^{-}$solution mass in experiment 2, which had higher transpiration water loss (SI Figure S2). Linear correlations that were independent of initial $\mathrm{ClO}_{4}{ }^{-}$concentration $\left(\mathrm{r}^{2}=\right.$ 0.82 and 0.96 for $2 \mathrm{mg} / \mathrm{L}$ and $10 \mathrm{mg} / \mathrm{L} \mathrm{ClO}_{4}{ }^{-}$, respectively, $\mathrm{P}<0.05$ ) were observed between the volume of solution transpired and the fraction of total $\mathrm{ClO}_{4}{ }^{-}$mass lost from solution in experiment 2 (Figure 1a). Insufficient time points were available to evaluate such correlations in experiment 1. Our results support previous work (Seyfferth and Parker, 2007) that suggests $\mathrm{ClO}_{4}{ }^{-}$mass lost from solution is directly proportional to the volume of transpired water, but less than the amount based on transpiration and solution $\mathrm{ClO}_{4}{ }^{-}$concentration (SI Figure S3). 
Like $\mathrm{ClO}_{4}{ }^{-}$mass, the $\mathrm{NO}_{3}{ }^{-}$mass in solutions of treatments with plants gradually decreased $(\sim 40-80 \%)$ over time in a non-linear fashion for all treatments with plants in both experiments (SI Figure S2). The $\mathrm{NO}_{3}{ }^{-}$fractional mass loss was linearly correlated $(\mathrm{P}<0.05)$ with the amount of solution transpired in all treatments with plants $\left(\mathrm{r}^{2}=0.76-0.86\right)$ (Figure 1c). Both $\mathrm{NO}_{3}{ }^{-}$and $\mathrm{ClO}_{4}{ }^{-}$had similar uptake rates as $\%$ of total mass/L transpired $(0.87 \pm 0.15$ to 0.99 $\pm 0.21)$ and $(0.97 \pm 0.08$ to $1.02 \pm 0.17)$, respectively, supporting a similar uptake mechanism as suggested by other studies (Figure 1a and c) (Seyfferth et al., 2008a).

In contrast to $\mathrm{ClO}_{4}{ }^{-}$and $\mathrm{NO}_{3}{ }^{-}, \mathrm{Cl}^{-}$mass in solution remained relatively constant $(\sim 80-$ $120 \%$ of initial total $\mathrm{Cl}^{-}$) throughout the experiments regardless of initial $\mathrm{ClO}_{4}{ }^{-}$treatment concentration, the presence or absence of plants, or $\mathrm{Cl}^{-}$concentration (e.g. experiment $1 \mathrm{Cl}^{-} \approx 1$ $\mathrm{mg} / \mathrm{L}$ and experiment $2 \mathrm{Cl}^{-} \approx 100 \mathrm{mg} / \mathrm{L}$ ) (SI Figure S2). There was no correlation between mass of $\mathrm{Cl}^{-}$removed from solution and the amount of solution transpired (Figure 1b). Although $\mathrm{Cl}^{-}$ clearly accumulated in plants (Table S1), the amount taken up was small compared to the amount in solution (experiment 2) or small compared to analytical uncertainty (experiment 2).

\subsubsection{Anion Distributions and Bioconcentration factors}

Bioconcentration factors (BCF, Equation 1) for $\mathrm{ClO}_{4}{ }^{-}$ranged from $55-70 \mathrm{~L} / \mathrm{kg}$ for all $\mathrm{ClO}_{4}{ }^{-}$exposure concentrations in both experiments, with the low and high values in this range corresponding to the $10 \mathrm{mg} / \mathrm{L} \mathrm{ClO}_{4}{ }^{-}$treatments of experiment 2 and experiment 1 , respectively. Our $\mathrm{ClO}_{4}{ }^{-} \mathrm{BCF}$ values were higher than those reported for lettuce exposed to 1.25 and $10 \mu \mathrm{g} / \mathrm{L}$ $\mathrm{ClO}_{4}^{-}(2-40 \mathrm{~L} / \mathrm{kg})$ (Seyfferth and Parker, 2007) but within range of those reported for spinach $(17-102 \mathrm{~L} / \mathrm{kg})\left(\mathrm{Ha}\right.$ et al., 2011) exposed to $4-40 \mu \mathrm{g} / \mathrm{L} \mathrm{ClO}_{4}{ }^{-}$. The distribution of $\mathrm{ClO}_{4}{ }^{-}$ between different plant tissues was independent of $\mathrm{ClO}_{4}{ }^{-}$exposure concentration in both experiments (SI Table S1). Of the $\mathrm{ClO}_{4}{ }^{-}$found in the plant, the majority was located in leaves (77-90\%), a finding consistent with past studies (Jackson et al., 2005; Seyfferth and Parker, 
2007; Voogt and Jackson, 2010). The next largest accumulation of $\mathrm{ClO}_{4}{ }^{-}$was detected in bean pods $(5-21 \%)$, followed by stems $(1.2-2.8 \%)$, and then roots $(1-2 \%)$.

Apparent $\mathrm{BCF}$ factors for $\mathrm{NO}_{3}{ }^{-}$for all exposure concentrations in both experiments (0.5-2 $\mathrm{L} / \mathrm{kg}$ ) were much smaller than the $\mathrm{ClO}_{4}{ }^{-} \mathrm{BCF}$ values because most of the $\mathrm{NO}_{3}{ }^{-}$was converted within plants to organic $\mathrm{N}$. Only a small fraction of the initial total $\mathrm{NO}_{3}{ }^{-}$mass was detected in plant tissues for both experiments $(0.3-5.0 \%)$, with the accumulation being higher in experiment 2 (SI Table S1). Accumulated $\mathrm{NO}_{3}{ }^{-}$was mainly located in the roots $(18-45 \%$ ), followed by the leaves $(22-39 \%)$, the stems $(14-33 \%)$, and then bean pods $(3-27 \%)$. In experiment 1 , in treatments with plants, most of the $\sim 41-45 \% \mathrm{NO}_{3}{ }^{-}$(as $\mathrm{N}$ ) that was lost from solution was recovered as $\mathrm{N}$ in plant tissues, as indicated by nearly complete recovery of the initial total N (SI Table S1). Experiment 1 BCF average values for total N were 158-181 L/kg for all plant treatments. Total $\mathrm{N}$ was not measured in experiment 2. The majority of total $\mathrm{N}$ accumulated in the plant was located in the bean pods $(39-44 \%)$ and the leaves $(34-43 \%)$, followed by the stems $(10-12 \%)$, and then roots $(8-10 \%)$.

The BCF values for $\mathrm{Cl}^{-}(1.9-8.8 \mathrm{~L} / \mathrm{kg} \mathrm{FW})$ in experiment 2 were much lower than those for $\mathrm{ClO}_{4}{ }^{-}$, supporting the selective uptake of $\mathrm{ClO}_{4}{ }^{-}$. The small amount of $\mathrm{Cl}^{-}$extracted from the plants was mainly found in the stems $(34-43 \%)$, followed by the leaves $(24-42 \%)$, the bean pods $(10-23 \%)$, and then roots $(9-24 \%)$ (SI Table S1).

\subsubsection{Isotopic Composition of Perchlorate}

The isotopic composition of $\mathrm{ClO}_{4}^{-}$in both the growth solutions and plant extracts were measured at plant maturity and compared to the initial isotopic composition of $\mathrm{ClO}_{4}{ }^{-}$in the growth solutions to evaluate any fractionation associated with either (1) uptake from solutions into the plants or (2) transformation or exchange within the plants after uptake. The isotopic compositions of $\mathrm{ClO}_{4}^{-}\left(\delta^{37} \mathrm{Cl}, \delta^{18} \mathrm{O}, \Delta^{17} \mathrm{O}\right)$ in leaves and hydroponic solutions were not 
consistently different from each other in either experiment using isotopically different $\mathrm{ClO}_{4}{ }^{-}$ sources ( $\mathrm{n}=4$ pairs) (Figure 2). For most experiments using isotopically anomalous $\mathrm{ClO}_{4}{ }^{-}$ (Figure $2 \mathrm{a}$ and $2 \mathrm{~b}$ ), small differences $(<1.5 \%$ ) between final growth solutions and leaf extracts were not systematically in one direction or the other, and likely represent small random variations in impurities or isotope effects of sample preparation (Sturchio et al., 2006; Böhlke et al., 2017). Experiments using isotopically anomalous $\mathrm{ClO}_{4}{ }^{-}$also exhibited small systematic differences between the $\delta^{18} \mathrm{O}$ and $\Delta^{17} \mathrm{O}$ values of the initial $\mathrm{ClO}_{4}{ }_{4}^{-}$reagent and final hydroponic solutions (1-2\%). Those offsets are not consistent with fractionation effects and are attributed to minor contaminants in the solution extract samples (Böhlke et al., 2017), which have much less effect on the results of experiments using isotopically normal $\mathrm{ClO}_{4}{ }^{-}$reagent (Figure $2 \mathrm{c}$ and 2d). One of the $2 \mathrm{mg} / \mathrm{L} \mathrm{ClO}_{4}{ }^{-}$replicate treatments in experiment 1 had anomalously high $\delta^{18} \mathrm{O}(\sim$ $7 \%$ above the initial value $)$ and $\delta^{37} \mathrm{Cl}(\sim 1-2 \%$ above the initial value $)$ in leaf tissue, but no difference in $\Delta^{17} \mathrm{O}$ (Figure 2a and $2 \mathrm{~b}$ ). That sample may have been isotopically fractionated (e.g., partially degraded), but it is not known if the anomalous result was caused by plant processes or subsequent handling of the organic-rich extract. $\mathrm{The}^{-} \mathrm{NO}_{3}{ }^{-}$extracted from that sample was not isotopically anomalous compared to others in the same experiment. For treatments with normal reagent $\mathrm{ClO}_{4}^{-}$(Figure $2 \mathrm{c}$ and 2d), small variations in $\delta^{37} \mathrm{Cl}$ and $\delta^{18} \mathrm{O}$ could be consistent with fractionation effects in growth solutions or plants, but overall variations were $\leq 1 \%$, which is similar to typical uncertainties of approximately $\pm 0.5 \%$ to $\pm 1.0 \%$ due to combined effects of $\mathrm{ClO}_{4}{ }^{-}$extraction, purification, and isotopic analysis of complex solutions. Overall, the data from both experiments indicate generally insignificant isotopic fractionation or exchange attributable to plant $\mathrm{ClO}_{4}{ }^{-}$uptake, plant $\mathrm{ClO}_{4}{ }^{-}$transformation, microbial $\mathrm{ClO}_{4}{ }^{-}$ transformation, or isotopic exchange between $\mathrm{ClO}_{4}{ }^{-}$and other constituents. 


\subsubsection{Isotopic Composition of Nitrate}

The $\delta^{15} \mathrm{~N}$ values of $\mathrm{NO}_{3}{ }^{-}$in hydroponic solutions increased slightly $(<2 \%)$ over time in both experiments for all treatments with plants but no increase was observed in control treatments without plants (Figure 3a and c). In experiment $1, \delta^{15} \mathrm{~N}$ increases were small but fairly constant throughout the growth period (Figure 3a), whereas in experiment 2 the increases did not occur until mid-way through the growth period (Figure 3c). In the two treatments with the largest $\delta^{15} \mathrm{~N}$ increases, $\delta^{18} \mathrm{O}$ also increased substantially (Figure $3 \mathrm{~d}$ ), whereas $\delta^{18} \mathrm{O}$ variations in other treatments were within normal analytical uncertainties (Figure 3b). Apparent isotope fractionation factors $(\varepsilon)$ derived from residual $\mathrm{NO}_{3}{ }^{-}$in both experiment growth solutions were of the order of -1.0 to $-1.5 \%$ for $\varepsilon^{15} \mathrm{~N}(\mathrm{P}<0.05)$ (SI Figure $\left.\mathrm{S} 4\right)$. The $\varepsilon^{18} \mathrm{O}$ values were generally insignificant $(\mathrm{P}>0.05)$ in both experiment solutions. Correlated increases in $\delta^{15} \mathrm{~N}$ and $\delta^{18} \mathrm{O}$ in late stages (last ten days) of two treatments in experiment 2 could indicate minor fractionation by plant uptake or $\mathrm{NO}_{3}{ }^{-}$reduction. Apparent $\varepsilon^{15} \mathrm{~N} / \varepsilon^{18} \mathrm{O}$ ratio values for $\mathrm{NO}_{3}{ }^{-}$in solutions of approximately $0.5-0.6$ were lower than reported experimental values for $\mathrm{NO}_{3}{ }^{-}$reduction $\left(\varepsilon^{15} \mathrm{~N} / \varepsilon^{18} \mathrm{O} \approx 1\right)$ and more like those reported for $\mathrm{NO}_{3}{ }^{-}$transport from solution into plants (Needoba et al., 2003; Needoba et al., 2004; Granger et al., 2010) (SI Figures S4 and S5).

The $\delta^{15} \mathrm{~N}$ and $\delta^{18} \mathrm{O}$ values of $\mathrm{NO}_{3}{ }^{-}$extracted from leaves were higher than those in the hydroponic solutions by about 10-20\% (Figure 4). These differences were similar in both experiments, even though the $\mathrm{NO}_{3}{ }^{-}$reagents used in the experiments had different initial isotopic compositions (Figure 4), consistent with isotopic fractionation of $\mathrm{NO}_{3}{ }^{-}$within the plants after uptake from growth solutions (Schmidt et al., 2015; Evans, 2001; Liu et al., 2012). In both experiments there were positive $(\mathrm{P}<0.001)$ correlations between $\delta^{15} \mathrm{~N}$ and $\delta^{18} \mathrm{O}$ values of leaves and growth solutions with slopes of 1.06 (experiment 1) and 1.04 (experiment 2). When evaluated using Equations 7 and 8, data from both experiments yielded $\varepsilon^{15} \mathrm{~N} / \varepsilon^{18} \mathrm{O}$ ratios of 1.05 , 
consistent with reported effects of $\mathrm{NO}_{3}{ }^{-}$reduction during assimilation by plants (Granger et al., 2004; Casciotti et al., 2002). In experiment $1, \delta^{15} \mathrm{~N}$ values were $\sim+54 \%$ for solution $\mathrm{NO}_{3}{ }^{-} \sim+$ $31 \%$ for final plant tissue, and $\sim+72 \%$ for final residual $\mathrm{NO}_{3}{ }^{-}$extracted from leaves (Figure 4a). These results are qualitatively consistent with isotope effects dominated by internal $\mathrm{NO}_{3}{ }^{-}$ reduction during assimilation (Karsh et al., 2012; Granger et al., 2004; Karsh et al., 2014).

\subsection{Snap Bean Field Studies}

In 2010, the isotopic composition of $\mathrm{ClO}_{4}{ }^{-}$in the Raleigh, $\mathrm{NC}$ snap bean crops was indistinguishable, given cumulative error terms $(< \pm 2 \%)$, from that of $\mathrm{ClO}_{4}{ }^{-}$in the groundwater used for irrigation (SI Table S3). The isotopic composition of $\mathrm{ClO}_{4}{ }^{-}$in the groundwater was similar to that of $\mathrm{ClO}_{4}{ }^{-}$from the Atacama Desert, indicating that a likely source of elevated $\mathrm{ClO}_{4}{ }^{-}$ in the groundwater was from the historical use of imported Chilean $\mathrm{NO}_{3}{ }^{-}$fertilizer (Böhlke et al., 2009; Böhlke et al., 2005). These data indicate the 2010 Raleigh snap bean crop accumulated Atacama-derived $\mathrm{ClO}_{4}{ }^{-}$from irrigation water without fractionating or otherwise altering its isotopic composition substantially, thus supporting the hydroponic results in a field setting. For

$\mathrm{ClO}_{4}{ }^{-}$from the 2009 snap bean crop, all three isotopic parameters $\left(\delta^{37} \mathrm{Cl}, \delta^{18} \mathrm{O}\right.$, and $\left.\Delta^{17} \mathrm{O}\right)$ were shifted slightly away from the 2010 values and plot near two-component mixing lines between the irrigation water data and values commonly attributed to indigenous natural $\mathrm{ClO}_{4}{ }^{-}$from uncontaminated soils and groundwaters in other areas of the U.S. (Figure 5)(Jackson et al., 2010; Poghosyan et al., 2014).

Differences in isotopic composition of $\mathrm{ClO}_{4}{ }^{-}$accumulated in snap beans in Raleigh, $\mathrm{NC}$ in 2009 and 2010 are qualitatively consistent with estimated differences in the masses of applied $\mathrm{ClO}_{4}{ }^{-}$from irrigation water and atmospheric deposition between years (SI Table S3). The snap bean crop received varying proportions of rainfall and groundwater irrigation in 2009 and 2010 . 
Concentrations of $\mathrm{ClO}_{4}{ }^{-}$in irrigation water also varied between 2009 and $2010(\sim 0.6$ and 2.2 $\mu \mathrm{g} / \mathrm{L}$, respectively), presumably due to exhaustion of the ion-exchange column installed to remove $\mathrm{ClO}_{4}{ }^{-}$from the groundwater used for irrigation. Although partial retention of $\mathrm{ClO}_{4}{ }^{-}$on the resin could have caused some isotopic fractionation of $\mathrm{ClO}_{4}{ }^{-}$in the irrigation water, previous studies indicate those effects are small compared to the differences observed in the Raleigh, NC study (Hatzinger et al., 2011; Böhlke et al., 2017). Furthermore, differences between 2009 and 2010 isotopic data included a substantial change in $\Delta^{17} \mathrm{O}$, which would be consistent with different sources but not with variable fractionation. The similarity between the snap bean and groundwater isotopic composition in 2010 is consistent with the much larger applied $\mathrm{ClO}_{4}{ }^{-}$mass from groundwater during the growing season in 2010, (480 $\mu \mathrm{g} / \mathrm{m}^{2}$-yr) compared to 2009 (48 $\mu \mathrm{g} / \mathrm{m}^{2}-\mathrm{yr}$ ) (SI Table S2). The intermediate isotopic composition of foliar $\mathrm{ClO}_{4}^{-}$in 2009 is consistent with a larger proportional contribution from indigenous $\mathrm{ClO}_{4}{ }^{-}$in atmospheric deposition when the groundwater $\mathrm{ClO}_{4}{ }^{-}$contribution was smaller. The annual average $\mathrm{ClO}_{4}{ }^{-}$ deposition rate in the US is $\sim 6.5 \mu \mathrm{g} / \mathrm{m}^{2}$-yr in precipitation, with an unknown contribution from dry deposition (Rajagopalan et al., 2009). The maximum $\mathrm{ClO}_{4}{ }^{-}$contribution from fertilizer was estimated to be less than $2.5 \mu \mathrm{g} / \mathrm{m}^{2}$. The higher mass of total $\mathrm{ClO}_{4}{ }^{-}$applied from both sources in 2010 is also reflected in a $\sim 4 \mathrm{X}$ higher foliar $\mathrm{ClO}_{4}{ }^{-}$concentration in $2010(3000-4000 \mu \mathrm{g} / \mathrm{kg}$ dry weight) than $2009(800-1000 \mu \mathrm{g} / \mathrm{kg}$ dry weight).

The isotopic composition of $\mathrm{ClO}_{4}{ }^{-}$in snap beans from Long Island appears to reflect multiple sources, possibly dominated by indigenous $\mathrm{ClO}_{4}{ }^{-}$and $\mathrm{Atacama}_{\mathrm{ClO}}{ }_{4}{ }^{-}$with a smaller contribution of synthetic $\mathrm{ClO}_{4}^{-}$(Figure 5). It is not possible to determine if the foliar $\mathrm{ClO}_{4}{ }^{-}$ isotopic composition is consistent with the contributing sources as no data are available for the isotopic composition of groundwater used for irrigation. Long Island groundwater has 
previously been shown to contain varying proportions of synthetic $\mathrm{ClO}_{4}{ }^{-}$and $\mathrm{Atacama}^{-} \mathrm{ClO}_{4}{ }^{-}$in some areas where $\mathrm{ClO}_{4}{ }^{-}$concentrations are relatively high (Böhlke et al., 2009). Given the low concentration of $\mathrm{ClO}_{4}^{-}$in groundwater used for irrigation at the Long Island experiment location $(\sim 0.3 \mu \mathrm{g} / \mathrm{L})$, any combination of two or more sources would not be unreasonable. Similar $\mathrm{ClO}_{4}{ }^{-}$ isotopic compositions have been reported for groundwater with similarly low $\mathrm{ClO}_{4}{ }^{-}$ concentrations from mixed sources in southern California (Hatzinger et al., 2015; Sturchio et al., 2014). Our data indicate that it may be possible to evaluate foliar $\mathrm{ClO}_{4}{ }^{-}$isotopic composition and origin in field-grown plants, even with near-background foliar $\mathrm{ClO}_{4}{ }^{-}$concentrations $(<400 \mu \mathrm{g} / \mathrm{kg}$ dry weight).

\subsection{Spinach Study Results}

We analyzed commercially grown spinach as another test of our extraction and analysis procedures and to evaluate potential sources of $\mathrm{ClO}_{4}{ }^{-}$in food products. The isotopic composition of $\mathrm{ClO}_{4}{ }^{-}$extracted from spinach $\left(\delta^{37} \mathrm{Cl}=+3.3 \%\right.$, $\delta^{18} \mathrm{O}=+3.7 \%$, $\Delta^{17} \mathrm{O}=+2.6 \%$ ) was similar to that reported for indigenous natural $\mathrm{ClO}_{4}^{-}$in soil and groundwater in the southwestern U.S. and surface waters of the Great Lakes, and to the inferred isotopic composition of natural $\mathrm{ClO}_{4}{ }^{-}$ in groundwater in parts of southern California (Figure 5) (Jackson et al., 2010; Böhlke et al., 2005; Hatzinger et al., 2015; Sturchio et al., 2006; Sturchio et al., 2014; Poghosyan et al., 2014).

\section{Discussion}

A number of processes could affect the stable isotopic composition of $\mathrm{ClO}_{4}{ }^{-}$accumulated in plants and potentially contribute to the reported ranges of natural $\mathrm{ClO}_{4}{ }^{-}$stable isotopic composition in soil and groundwater. Uptake of $\mathrm{ClO}_{4}{ }^{-}$by ion transporters, plant-catalyzed reduction, or oxygen exchange could all potentially cause isotopic fractionation. Our study is the first to directly use stable isotopic analyses of $\mathrm{ClO}_{4}{ }^{-}$extracted from plant tissues to evaluate the potential of plant processes to alter $\mathrm{ClO}_{4}{ }^{-}$through fractionation or exchange. 
Snap bean plants were found to selectively uptake $\mathrm{ClO}_{4}{ }^{-}$relative to $\mathrm{Cl}^{-}$, but not relative to $\mathrm{NO}_{3}{ }^{-}$, supporting a common ion transport mechanism for $\mathrm{ClO}_{4}{ }^{-}$and $\mathrm{NO}_{3}{ }^{-}$. The similarity in uptake rates for $\mathrm{ClO}_{4}{ }^{-}$and $\mathrm{NO}_{3}{ }^{-}$, the strong correlation of anion uptake with volume of transpired solution, and the partial exclusion of $\mathrm{ClO}_{4}{ }^{-}$relative to the mass of transpired water, are all consistent with findings from a previous study (Seyfferth et al., 2008a). This suggests that transport is through an ion carrier in the roots that is specific to both $\mathrm{NO}_{3}{ }^{-}$and $\mathrm{ClO}_{4}{ }^{-}$but is also dependent on transpiration rate (Seyfferth et al., 2008a).

No substantial differences were observed in the $\delta^{37} \mathrm{Cl}, \delta^{18} \mathrm{O}$, or $\Delta^{17} \mathrm{O}$ values of $\mathrm{ClO}_{4}{ }^{-}$ between the growth solutions and leaf extracts during hydroponic experiments despite a large isotopic fractionation of residual $\mathrm{NO}_{3}{ }^{-}$in leaf extracts. Changes in $\delta^{15} \mathrm{~N}$ and $\delta^{18} \mathrm{O}$ of $\mathrm{NO}_{3}{ }^{-}$in growth solutions were small but measurable in two treatments. If minor isotopic fractionation by bacterial $\mathrm{NO}_{3}{ }^{-}$reduction or transport into plants was responsible for these changes in growth solutions, those processes did not have a measurable effect on residual $\mathrm{ClO}_{4}{ }^{-}$in the growth solutions. Although some of the $\mathrm{ClO}_{4}{ }^{-}$mass in experiment 1 was not accounted for, data from experiment 2 indicate $\mathrm{ClO}_{4}{ }^{-}$mass was largely conserved. Furthermore, the essentially identical stable isotopic compositions of $\mathrm{ClO}_{4}{ }^{-}$in source reagents, growth solutions, and leaf tissues in both experiments makes it unlikely that substantial transformation of $\mathrm{ClO}_{4}{ }^{-}$occurred, as previous studies indicate enzymatic $\mathrm{ClO}_{4}{ }^{-}$reduction is accompanied by large isotope fractionation effects (Sturchio et al., 2007; Hatzinger et al., 2009; Sturchio et al., 2003). Our results, in combination with another published study (Seyfferth 2008b), suggest that plant-mediated $\mathrm{ClO}_{4}{ }^{-}$ transformation may not be common. If isotopic fractionation of $\mathrm{ClO}_{4}{ }^{-}$occurred during uptake or if plant-mediated exchange of $\mathrm{O}$ occurred between $\mathrm{ClO}_{4}{ }^{-}$and other compounds such as $\mathrm{H}_{2} \mathrm{O}$, 
then the magnitude of exchange was too small to detect in these experiments (i.e., $\leq 2 \%$ exchange in a growing season).

In contrast to $\mathrm{ClO}_{4}{ }^{-}, \delta^{15} \mathrm{~N}$ and $\delta^{18} \mathrm{O}$ of $\mathrm{NO}_{3}{ }^{-}$in plant tissue was fractionated substantially (by about $10-20 \%$, relative to $\mathrm{NO}_{3}{ }^{-}$in growth solutions), consistent with reported effects of $\mathrm{NO}_{3}{ }^{-}$assimilation (Needoba et al., 2004; Granger et al., 2010; Ledgard et al., 1985). The $\varepsilon^{15} \mathrm{~N} / \varepsilon^{18} \mathrm{O}$ ratios of 1.05 observed in our study support previous experimental studies indicating that isotopic fractionation by assimilatory nitrate reductase has an intrinsic $\varepsilon^{15} \mathrm{~N} / \varepsilon^{18} \mathrm{O}$ ratio of approximately 1 , regardless of the magnitudes of $\varepsilon^{15} \mathrm{~N}$ and $\varepsilon^{18} \mathrm{O}$ values expressed (Karsh et al., 2012; Granger et al., 2004; Karsh et al., 2014).

The isotope effects of assimilation and storage of $\mathrm{NO}_{3}{ }^{-}$in plant tissue, as well as isotope effects attributed to both uptake and efflux of $\mathrm{NO}_{3}{ }^{-}$, are not all known, but our study provides information that could improve applicability of plant leachate $\mathrm{NO}_{3}{ }^{-}$isotopes as indicators of fertilization history. Recent studies (Laursen et al., 2013; Mihailova et al., 2014) have suggested that isotopic analyses of $\mathrm{NO}_{3}{ }^{-}$extracted from plants could be used to distinguish between organically and conventionally grown crops (Laursen et al., 2013; Mihailova et al., 2014). The O and $\mathrm{N}$ fractionation ratio $\left(\varepsilon^{15} \mathrm{~N} / \varepsilon^{18} \mathrm{O} \approx 1\right)$ in our study could be used to constrain the isotopic composition of a fertilizer source after it has undergone varying amounts of fractionation in plants. Furthermore, because $\mathrm{ClO}_{4}{ }^{-}$has been a component of some natural $\mathrm{NO}_{3}{ }^{-}$fertilizers, various combinations of $\mathrm{NO}_{3}{ }^{-}$isotopes, $\mathrm{ClO}_{4}{ }^{-}$concentrations, and $\mathrm{ClO}_{4}{ }^{-}$isotopes in plant extracts may be useful in identifying natural $\mathrm{NO}_{3}{ }^{-}$fertilizer components. For instance, natural $\mathrm{NO}_{3}{ }^{-}$ fertilizer with high $\delta^{18} \mathrm{O}$ and $\Delta^{17} \mathrm{O}$ from the Atacama Desert might be recognized from its unusual isotopic composition (Böhlke et al., 1997; Michalski et al., 2004). Even where Atacama $\mathrm{NO}_{3}{ }^{-}$only makes up a small fraction of total $\mathrm{N}$ applications, it can contain substantial amounts of 
$\mathrm{ClO}_{4}{ }^{-}$. Therefore, $\mathrm{ClO}_{4}{ }^{-}$concentrations and isotope ratios could also be used as a marker to detect the use of natural inorganic $\mathrm{NO}_{3}{ }^{-}$fertilizers from the Atacama Desert (Böhlke et al., 2009) or the presence of $\mathrm{ClO}_{4}{ }^{-}$in irrigation water (this study).

Our study indicates that some field-grown plants exposed to environmentally relevant $\mathrm{ClO}_{4}{ }^{-}$concentrations can accumulate $\mathrm{ClO}_{4}^{-}{ }^{-}$in leaf tissues without substantial isotopic alteration. Snap bean crops grown in Raleigh, $\mathrm{NC}$ and Long Island, $\mathrm{NY}$ had $\mathrm{ClO}_{4}{ }^{-}$isotopic compositions consistent with known or inferred local sources including irrigation water and atmospheric deposition. $\mathrm{ClO}_{4}{ }^{-}$extracted from commercial spinach grown in the western United States had an isotopic composition similar to that of indigenous natural $\mathrm{ClO}_{4}{ }_{4}^{-}$from the southwestern United States and the Great Lakes (Jackson et al., 2010; Sturchio et al., 2014; Poghosyan et al., 2014). The low concentrations of $\mathrm{ClO}_{4}{ }^{-}$in the spinach are consistent with exposure to low concentrations of indigenous natural $\mathrm{ClO}_{4}{ }^{-}$previously reported in soil and groundwater (Jackson et al., 2010; Jackson et al., 2015). Although this spinach represents only one composite sample, and we have no direct knowledge about $\mathrm{ClO}_{4}{ }^{-}$in fertilizer or irrigation water used to grow the spinach, these results, combined with those of the field experiments and hydroponic studies with snap beans, suggest that it may be possible to evaluate the source of $\mathrm{ClO}_{4}{ }^{-}$in some types of plants including commercial produce and in other plant-based food products. This finding is important because most of the exposure to $\mathrm{ClO}_{4}{ }^{-}$in the U.S. population, and likely the population of many other countries, is through produce (Jackson et al., 2005; Sanchez et al., 2005) Isotopic analyses of $\mathrm{ClO}_{4}^{-}$in plants is a useful method for characterizing the isotopic composition of $\mathrm{ClO}_{4}^{-}$in the irrigation water or fertilizer used for cultivation. Locations and times at which produce is grown are not always known. Fertilizers, irrigation water sources, and/or sources of $\mathrm{ClO}_{4}{ }^{-}$in irrigation water or soils can vary in a given location and some produce is from multiple 
growers or is imported from other countries. Thus, isotope-ratio measurements of plant tissue provide a direct method to distinguish the dominant sources of $\mathrm{ClO}_{4}{ }^{-}$in the food chain. Our results also have implications in the field of phytoremediation as $\mathrm{ClO}_{4}{ }^{-}$isotopes might be useful for assessing whether plants are taking up targeted contaminant sources and would help improve the management and disposal of phytoremediation products if the $\mathrm{ClO}_{4}{ }^{-}$is not broken down and can be returned to the soil and groundwater when plants turnover. In addition, our study illustrates that testing of irrigation water supplies may be important for minimizing $\mathrm{ClO}_{4}{ }^{-}$ contamination of produce. In areas where irrigation wells tap groundwater containing legacy $\mathrm{ClO}_{4}{ }^{-}$from agricultural use of natural nitrate fertilizers from the Atacama Desert (as in our Raleigh, NC study), it may be possible either to treat it, or to switch to shallower (younger) or deeper (older) groundwater sources that were recharged when $\mathrm{ClO}_{4}{ }^{-}$loading from those fertilizers was less (Böhlke et al., 2009).

It is possible that hydroponic studies may not fully reflect uptake processes in normal soil-plant systems and that snap beans may not represent other plant types. However, our results indicate $\mathrm{ClO}_{4}{ }^{-}$uptake and accumulation can occur without significant net loss or isotope effects and that plant $\mathrm{NO}_{3}{ }_{3}^{-}$reduction systems efficiently exclude $\mathrm{ClO}_{4}{ }^{-}$, in contrast to some microbial $\mathrm{NO}_{3}{ }^{-}$reducing systems that can reduce both $\mathrm{NO}_{3}{ }^{-}$and $\mathrm{ClO}_{4}{ }^{-}$(Hatzinger et al., 2009). These results suggest that isotopic characteristics of $\mathrm{ClO}_{4}{ }^{-}$in soils and groundwater may not be affected by plant uptake and release. Therefore, our results contradict the hypothesis that plant uptake is a major cause of variation in $\mathrm{ClO}_{4}{ }^{-}$stable isotopic composition observed in natural systems. Given the relatively large contribution of U.S. human exposure through food, further studies may be warranted to determine sources of $\mathrm{ClO}_{4}{ }^{-}$in the food chain, as well as to determine if other types of plants in other settings can alter the isotopic composition of $\mathrm{ClO}_{4}{ }^{-}$. 


\section{Acknowledgements}

This work was supported by the U.S. Department of Defense Strategic Environmental Research and Development Program (SERDP -1435) and the U.S. Geological Survey (USGS) National Research Program and Toxic Substances Hydrology Program. The assistance of Oak Ridge National Laboratory, which is managed by UT-Battelle LLC for the U.S. Department of Energy under contract DE-AC05-00OR22725, is also gratefully acknowledged. We would also like to thank Janet Hannon (USGS), Stanley Mroczkowski (USGS), and Linnea Heraty (University of Illinois at Chicago) for conducting stable isotope analyses. Any use of trade, firm, or product names is for descriptive purposes only and does not imply endorsement by the U.S. Government.

\section{Supporting Information Available}

An Excel workbook containing primary data for hydroponic experiments, plus additional Tables S1-S3, and additional Figures S1-S5 are provided. 
Böhlke, J. K.; Hatzinger, P. B.; Sturchio, N. C.; Gu, B.; Abbene, I.; Mroczkowski, S. J. Atacama Perchlorate as an Agricultural Contaminant in Groundwater: Isotopic and Chronologic Evidence from Long Island, New York. Environ. Sci. Technol. 2009, 43 (15), 56195625.

Böhlke, J. K.; Sturchio, N. C.; Gu, B.; Horita, J.; Brown, G. M.; Jackson, W. A.; Batista, J.; Hatzinger, P. B. Perchlorate Isotope Forensics. Anal. Chem. 2005, 77 (23), 7838-7842.

Böhlke, J. K.; Mroczkowski, S. J.; Coplen, T. B. Oxygen Isotopes In Nitrate: New reference Materials for 180: 170: 160 Measurements and Observations On Nitrate-Water Equilibration. Rapid Commun. Mass Sp. 2003, 17 (16), 1835-1846.

Böhlke, J. K.; Smith, R. L.; Hannon, J. E. Isotopic Analysis of N and O in Nitrite and Nitrate by Sequential Selective Bacterial Reduction to N2O. Anal. Chem. 2007, 79 (15), 5888-5895.

Böhlke, J.K.; Ericksen, G.E.; Revesz, K. Stable Isotope Evidence for an Atmospheric Origin of Desert Nitrate Deposits in Northern Chile and Southern California. Chem. Geol. 1997, $136,135-152$.

Böhlke, J.K.; Mroczkowski, S.J.; Sturchio, N.C.; Heraty, L.J.; Richman, K.W.; Sullivan, D.B.; Griffith, K.N.; Gu, B.; Hatzinger, P.B. Stable Isotope Analyses of Oxygen $\left({ }^{18} \mathrm{O}:{ }^{17} \mathrm{O}\right.$ : $\left.{ }^{16} \mathrm{O}\right)$ and Chlorine $\left({ }^{37} \mathrm{Cl}:{ }^{35} \mathrm{Cl}\right)$ in Perchlorate: Reference Materials, Calibrations, and Interferences. Rapid Commun Mass Spectrom. 2017.

Burkey, K.O.; Miller, J.E.; Fiscus, E.L. Assesment of Ambient Ozone effects on Vegetation Using Snap Bean as a Bio-indicator Species. J. Environ. Qual. 2005, 34, 1081-1086.

Casciotti, K. L.; Sigman, D. M.; Hastings, M. G.; Böhlke, J. K.; Hilkert, A. Measurement of the Oxygen Isotopic Composition of Nitrate In Seawater and Freshwater Using the Denitrifier Method. Anal. Chem. 2002, 74 (19), 4905-4912.

Casciotti, K.L.; Böhlke, J.K.; Mcllvin, M.R.; Mroczkowski, S.J.; Hannon, J.E. Oxygen Isotopes in Nitrite: Analysis, Calibration, and Equilibration. Anal. Chem. 2007, 79(6), 2427-2436.

Dasgupta, P. K.; Dyke, J. V.; Kirk, A. B.; Jackson, W. A. Perchlorate In the United States. Analysis of Relative Source Contributions to the Food Chain. Environ. Sci. Technol. 2006, 40 (21), 6608-6614.

Desaulniers, D. E.; Kaufmann, R. S.; Cherry, J. A.; Bentley, H. W. ${ }^{37} \mathrm{Cl}^{-35} \mathrm{Cl}$ Variations In a Diffusion-controlled Groundwater System. Geochim. Cosmochim. Ac. 1986, 50 (8), 1757-1764.

Drinking Water: Regulatory Determination on Perchlorate. U.S. Environmental Protection Agency (USEPA), 2011, 7762-7767. 
Ellington, J. J.; Evans, J. J. Determination of Perchlorate At Parts-Per-Billion Levels In Plants by Ion Chromatography. J. Chromatogr. A 2000, 898 (2), 193-199.

Evans, R.D. Physiological Mechanisms Influencing Plant Nitrogen Isotope Composition. Trends Plant Sci. 2001, 6 (3), 121-126.

Farquhar, G. D.; Ehleringer, J. R.; Hubick, K. T. Carbon Isotope Discrimination and Photosynthesis. Annu. Rev. Plant Biol. 1989, 40 (1), 503-537.

Granger, J.; Sigman, D. M.; Needoba, J. A.; Harrison, P. J. Coupled Nitrogen and Oxygen Isotope Fractionation of Nitrate During Assimilation by Cultures of Marine Phytoplankton. Limnol. and Oceanogr. 2004, 49 (5), 1763-1773.

Granger, J.; Sigman, D. M.; Rohde, M. M.; Maldonado, M. T.; Tortell, P. D. N and O Isotope Effects During Nitrate Assimilation by Unicellular Prokaryotic and Eukaryotic Plankton Cultures. Geochim. Cosmochim. Ac. 2010, 74 (3), 1030-1040.

Greer, M. A.; Goodman, G.; Pleus, R. C.; Greer, S. E. Health Effects Assessment for Environmental Perchlorate Contamination: the Dose Response for Inhibition of Thyroidal Radioiodine Uptake in Humans. Environ. Health Persp. 2002, 110 (9), 927-937.

Ha, W.; Suarez, D. L.; Lesch, S. M. Perchlorate Uptake in Spinach as Related to Perchlorate, Nitrate, and Chloride Concentrations In Irrigation Water. Environ. Sci. Technol. 2011, 45 (21), 9363-9371.

Hatzinger, P. B.; Böhlke, J. K.; Sturchio, N. C.; Gu, B.; Heraty, L. J.; Borden, R. C. Fractionation of Stable Isotopes In Perchlorate and Nitrate During In Situ Biodegradation In a Sandy Aquifer. Environ. Chem. 2009, 6 (1), 44-52.

Hatzinger, P. B.; Böhlke, J. K.; Sturchio, N. C.; Gu, B. Guidance Manual for Forensic Analysis of Perchlorate In Groundwater Using Chlorine and Oxygen Isotopic Analyses.; ESTC Project ER-200509; 2011.

Hatzinger, P.B.; Böhlke, J.K.; Sturchio, N.C.; Izbicki, J.A.; Teague, N. Evaluation of Perchlorate Sources in the Rialto-Colton and Chino California Subbasins Using Chlorine and Oxygen Isotope Ratio Analysis. U.S. Department of Defense; Environmental Science and Technology Certification Program, online report, 2015.

Hoering, T. C.; Ishimori, F. T.; McDonald, H. O. The Oxygen Exchange Between Oxy-anions and Water. II. Chlorite, Chlorate and Perchlorate Ions1. J. Am. Chem. Soc. 1958, 80 (15), 3876-3879. 
Jackson, W. A.; Böhlke, J. K.; Gu, B.; Hatzinger, P. B.; Sturchio, N. C. Isotopic Composition and Origin of Indigenous Natural Perchlorate and Co-Occurring Nitrate in the Southwestern United States. Environ. Sci. Technol. 2010, 44 (13), 4869-4876.

Jackson, W. A.; Joseph, P.; Laxman, P.; Tan, K.; Smith, P. N.; Yu, L.; Anderson, T. A. Perchlorate Accumulation in Forage and Edible Vegetation. J. Agr. Food Chem. 2005, 53 (2), 369-373.

Jackson, W.A.; Böhlke, J.K.; Andraski, B.J.; Fahlquist, L.; Bexfield, L.; Eckardt, F.D.; Gates, J.B.; Davila, A.F.; McKay, C.P.; Rao, B.; Sevanthi, R.; Rajagopalan, S.; Estrada, N.; Sturchio, N.; Hatzinger, P.B.; Anderson, T.A.; Orris, G.; Betancourt, J.; Stonestrom, D.; Latorre, C.; Li, Y.; Harvey, G.J. Global Patterns and Environmental Controls of Perchlorate and Nitrate Co-occurrence in Arid and Semi-arid Environments. Geochim. Cosmochim. Ac. 2015, 164, 502-522.

Jackson, W.A.; Davila, A.F.; Sears, D.W.G.; Coates, J.D.; McKay, C.P.; Brundrett, M.; Estrada, N.; Böhlke, J.K. Widespread Occurrence of (Per)chlorate in the Solar System. Earth Planet Sc. Lett. 2015, 430, 470-476.

Karsh, K. L.; Granger, J.; Kritee, K.; Sigman, D. M. Eukaryotic Assimilatory Nitrate Reductase Fractionates $\mathrm{N}$ and $\mathrm{O}$ isotopes With a Ratio Near Unity. Environ. Sci. Technol. 2012, 46 (11), 5727-5735.

Karsh, K.L.; Trull, T.W.; Sigman, D.M.; Thompson, P.A.; Granger, J. The Contributions of Nitrate Uptake and Efflux to Isotope Fractionation During Algal Nitrate Assimilation. Geochim. Cosmochim. Ac. 2014, 132, 391-412.

Kaufmann, R. S.; Frape, S. K.; McNutt, R.; Eastoe, C. Chlorine Stable Isotope Distribution of Michigan Basin Formation Waters. Appl. Geochem. 1993, 8 (4), 403-407.

Kirk, A. B.; Smith, E. E.; Tian, K.; Anderson, T. A.; Dasgupta, P. K. Perchlorate in Milk. Environ. Sci. Technol. 2003, 37 (21), 4979-4981.

Kirk, A.B.; Dyke, J.V.; Martin, C.F.; Dasgupta, P.K. Temporal Patterns in Perchlorate, Thiocyanate, and Iodide Excretion in Human Milk. Environ. Health Persp. 2007, 115 (2), 182-186.

Kounaves, S. P.; Stroble, S. T.; Anderson, R. M.; Moore, Q.; Catling, D. C.; Douglas, S.; McKay, C. P.; Ming, D. W.; Smith, P. H.; Tamppari, L. K.; Zent, A. P. Discovery of Natural Perchlorate in the Antarctic Dry Valleys and Its Global Implications. Environ. Sci. Technol. 2010, 44 (7), 2360-2364.

Laursen, K. H.; Mihailova, A.; Kelly, S. D.; Epov, V. N.; Bérail, S.; Schjoerring, J. K.; Donard, O. F. X.; Larsen, E. H.; Pedentchouk, N.; Marca-Bell, A. D.; Halekoh, U.; Olesen, J. E.; Husted, S. Is it Really Organic? - Multi-isotopic Analysis As a Tool to Discriminate Between Organic and Conventional Plants. Food Chem. 2013, 141 (3), 2812-2820. 
Ledgard, S. F.; Woo, K. C.; Bergersen, F. J. Isotopic Fractionation During Reduction of Nitrate and Nitrite by Extracts of Spinach Leaves. Funct. Plant Biol. 1985, 12 (6), 631-640.

Liu, X.Y.; Koba, K.; Yoh, M.; Liu, C.Q. Nitrogen and Oxygen Isotope Effects of Tissue Nitrate Associated With Nitrate Acquisition and Utilisation in the Moss Hypnum Plumaeforme.

Funct. Plant Biol. 2012, 39, 598-608.

Maixner, F.; Wagner, M.; Lücker, S.; Pelletier, E.; Schmitz-Esser, S.; Hace, K.; Spleck, E.; Konrat, R.; Paslier, D.L.; Dalms, H. Environmental Genomics Reveals a Functional Chlorite Dismutase in the Nitrite-Oxidizing Bacterium 'Candidatus Nitrospira defluvii'. Environ. Microbiol. 2008, 10 (11), 3043-3056.

Mariotti, A.; Mariotti, F.; Champigny, M.L.; Amarger, N.; Moyse, A. Nitrogen Isotope Fractionation Associated With Nitrate Reductase Activity and Uptake of NO3- by Pearl Millet. Plant Physiol. 1982, 69 (4), 880-884.

Marshall, J.D.; Brooks, J.R.; Lajtha, K. Chapter 2: Sources of Variation in the Stable Isotopic Composition of Plants. In Stable Isotopes in Ecology and Environmental Science (Second Edition); Michener, R.; Lajtha, K., Eds.; Blackwell Publishing: Malden, MA, 2007; pp 22-60.

Michalski, G.; Böhlke, J.K.; Thiemens, M.H. Long Term Atmospheric Deposition as the Source of Nitrate and Other Salts in the Atacama Desert, Chile: New Evidence From MassIndependent Oxygen Isotopic Compositions. Geochim. Cosmochim. Ac. 2004, 68, 40234038 .

Mihailova, A.; Pedentchouk, N.; Kelly, S. D. Stable Isotope Analysis of Plant-Derived NitrateNovel Method for Discrimination Between Organically and Conventionally Grown Vegetables. Food Chem. 2014, 154, 238-245.

Needoba, J. A.; Sigman, D. M.; Harrison, P. J. The Mechanism of Isotope Fractionation During Algal Nitrate Assimilation As Illuminated by the ${ }^{15} \mathrm{~N} /{ }^{14} \mathrm{~N}$ of Intracellular Nitrate. $J$. Phycol. 2004, 40 (3), 517-522.

Needoba, J. A.; Waser, N. A.; Harrison, P. J.; Calvert, S. E. Nitrogen Isotope Fractionation in 12 species of Marine Phytoplankton During Growth On Nitrate. Mar. Ecol. Prog. Ser. 2003, $255,81-91$.

Newman, M.C.; Clements, W.H. Fate and Transport of Contaminants in Ecosystems. In Ecotoxicology: A Comprehensive Treatment; CRS Press: Boca Raton, FL, 2008; 737 769. 
Poghosyan, A.; Sturchio, N.C.; Morrison, C.G.; Beloso Jr., A.D.; Guan, Y.; Eiler, J.M.; Jackson, W.A.; Hatzinger, P.B. Perchlorate in The Great Lakes: Isotopic Composition and Origin. Envir. Sci. Tech. 2014, 48, 11146-11153.

Rajagopalan, S.; Anderson, T.; Cox, S.; Harvey, G.; Cheng, Q.; Jackson, W. A. Perchlorate in Wet Deposition Across North America. Environ. Sci. Technol. 2009, 43 (3), 616-622.

Ransom, B.; Spivack, A. J.; Kastner, M. Stable Cl Isotopes In Subduction-zone Pore Waters: Implications for Fluid-rock Reactions and the Cycling of Chlorine. Geology 1995, 23 (8), 715-718.

Rao, B.; Anderson, T. A.; Orris, G. J.; Rainwater, K. A.; Rajagopalan, S.; Sandvig, R. M.; Scanlon, B. R.; Stonestrom, D. A.; Walvoord, M. A.; Jackson, W. A. Widespread Natural Perchlorate in Unsaturated Zones of the Southwest United States. Environ. Sci. Technol. 2007, 41 (13), 4522-4528.

Sanchez, C. A.; Crump, K. S.; Krieger, R. I.; Khandaker, N. R.; Gibbs, J. P. Perchlorate and Nitrate in Leafy Vegetables of North America. Environm. Sci. Technol. 2005, 39 (24), 9391-9397.

Schmidt, H.L.; Robins, R.J.; Werner, R.A. Multi-factoral In Vivo Stable Isotope Fractionation: Causes, Correlations, Consequences and Applications. Isot. Environ. Healt. S. 2015, 51 (1), 155-199.

Seyfferth, A. L.; Henderson, M. K.; Parker, D. R. Effects of Common Soil Anions and PH on the Uptake and Accumulation of Perchlorate In Lettuce. Plant Soil 2008a, 302 (1-2), 139-148.

Seyfferth, A. L.; Parker, D. R. Effects of Genotype and Transpiration Rate on the Uptake and Accumulation of Perchlorate $\left(\mathrm{ClO}_{4}^{-}\right)$in Lettuce. Environ. Sci. Technol. 2007, 41 (9), 3361-3367.

Seyfferth, A. L.; Sturchio, N. C.; Parker, D. R. Is Perchlorate Metabolized or Re-translocated Within Lettuce Leaves? A Stable-isotope Approach. Environ. Sci. Technol. 2008b, 42 (24), 9437-9442.

Sigman, D.M.; Casciotti, K.L.; Andreani, M.; Barford, C.; Galanter, M.; Böhlke, J.K. A Bacterial Method for the Nitrogen Isotopic Analysis of Nitrate in Seawater and Freshwater. Anal. Chem. 2001, 73, 4145-4153.

Sturchio, N.C.; Beloso Jr., A.; Heraty, L.J; Wheatcraft, S.; Schumer, R. Isotopic Tracing of Perchlorate Sources in Groundwater from Pomona, California. Appl. Geochem. 2014, $43,80-87$. 
Sturchio, N. C.; Böhlke, J. K.; Beloso, A. D.; Streger, S. H.; Heraty, L. J.; Hatzinger, P. B. Oxygen and Chlorine Isotopic Fractionation during Perchlorate Biodegradation: Laboratory Results and Implications for Forensics and Natural Attenuation Studies. Environ. Sci. Technol. 2007, 41 (8), 2796-2802.

Sturchio, N. C.; Böhlke, J. K.; Gu, B.; Hatzinger, P. B.; Jackson, W. A. Isotopic Tracing of Perchlorate in the Environment. In Handbook of Environmental Isotope Geochemistry; Baskaran, M., Ed. Springer-Verlag Berlin Heidelberg: London, New York, 2011; Vol. 1, pp 437-452.

Sturchio, N. C.; Böhlke, J. K.; Gu, B.; Horita, J.; Brown, G. M.; Beloso Jr, A. D.; Patterson, L. J.; Hatzinger, P. B.; Jackson, W. A.; Batista, J. Stable Isotopic Composition of Chlorine and Oxygen In Synthetic and Natural Perchlorate. In Perchlorate: Environmental Occurence, Interactions and Treatment; Gu, B.; Coates, J. D., Eds.; Springer: New York, 2006; pp 93-109.

Sturchio, N. C.; Hatzinger, P. B.; Arkins, M. D.; Suh, C.; Heraty, L. J. Chlorine Isotope Fractionation during Microbial Reduction of Perchlorate. Environ. Sci. Technol. 2003, 37 (17), 3859-3863.

Van Aken, B.; Schnoor, J. L. Evidence of Perchlorate $\left(\mathrm{ClO}_{4}{ }^{-}\right)$Reduction in Plant Tissues (Poplar Tree) Using Radio-Labeled ${ }^{36} \mathrm{ClO}_{4}^{-}$. Environ. Sci. Technol. 2002, 36 (12), 2783-2788.

Voogt, W.; Jackson, W. A. Perchlorate, Nitrate, and Iodine Uptake and Distribution In Lettuce (Lactuca Sativa L.) and Potential Impact on Background Levels In Humans. J. Agr. Food Chem. 2010, 58 (23), 12192-12198.

Werner, R.A.; Schmidt, H.L. The In Vivo Nitrogen Isotope Discrimination Among Organic Plant Compounds. Phytochemistry. 2002, 61, 465-484. 
Table 1. Summary of initial experimental conditions for $\mathrm{ClO}_{4}{ }^{-}$treatments in experiment 1 and 2. Experiment 1 was conducted during the months of October and December while experiment 2 was conducted during April and May.

\begin{tabular}{|c|c|c|c|c|c|c|c|c|}
\hline \multirow[t]{2}{*}{ Parameter } & \multicolumn{4}{|c|}{$\begin{array}{c}\text { Experiment } 1 \\
\mathrm{ClO}_{4}^{-} \text {Treatments }(\mathrm{mg} / \mathrm{L})\end{array}$} & \multicolumn{4}{|c|}{$\begin{array}{c}\text { Experiment } 2 \\
\mathrm{ClO}_{4}^{-} \text {Treatments }(\mathrm{mg} / \mathrm{L})\end{array}$} \\
\hline & 0 & 1 & 2 & 10 & 0 & 1 & 0.01 & 10 \\
\hline $\mathrm{Cl}^{-}(\mathrm{mg} / \mathrm{L})$ & $1.2(0)$ & $1.0(0)$ & $1.3(0.4)$ & $1.7(0.3)$ & $103(0)$ & $105(0)$ & $108(1)$ & $108(3)$ \\
\hline $\mathrm{NO}_{3}{ }^{-}-\mathrm{N}(\mathrm{mg} / \mathrm{L})$ & $274(0)$ & $268(0)$ & $274(3)$ & $264(13)$ & $237(0)$ & $240(0)$ & $237(2)$ & $235(4)$ \\
\hline $\mathrm{PO}_{4}{ }^{3-}(\mathrm{mg} / \mathrm{L})$ & $48(0)$ & $46(0)$ & $72(17)$ & $59(23)$ & $72(0)$ & $74(0)$ & $76(5)$ & $70(1)$ \\
\hline $\mathrm{SO}_{4}{ }^{2-}(\mathrm{mg} / \mathrm{L})$ & $117(0)$ & $110(0)$ & $116(2)$ & $113(9)$ & $130(0)$ & $137(0)$ & $144(12)$ & $142(15)$ \\
\hline \# tubs (replicates) & 1 & 1 & 4 & 2 & 1 & 1 & 2 & 2 \\
\hline Plants per tub & 6 & 0 & 6 & 6 & 4 & 0 & 4 & 4 \\
\hline
\end{tabular}

Anion concentrations reported are the means of the replicates for each $\mathrm{ClO}_{4}{ }^{-}$treatment. Standard errors of the means are indicated in parenthesis (e.g. Mean $( \pm S D)$ ). 

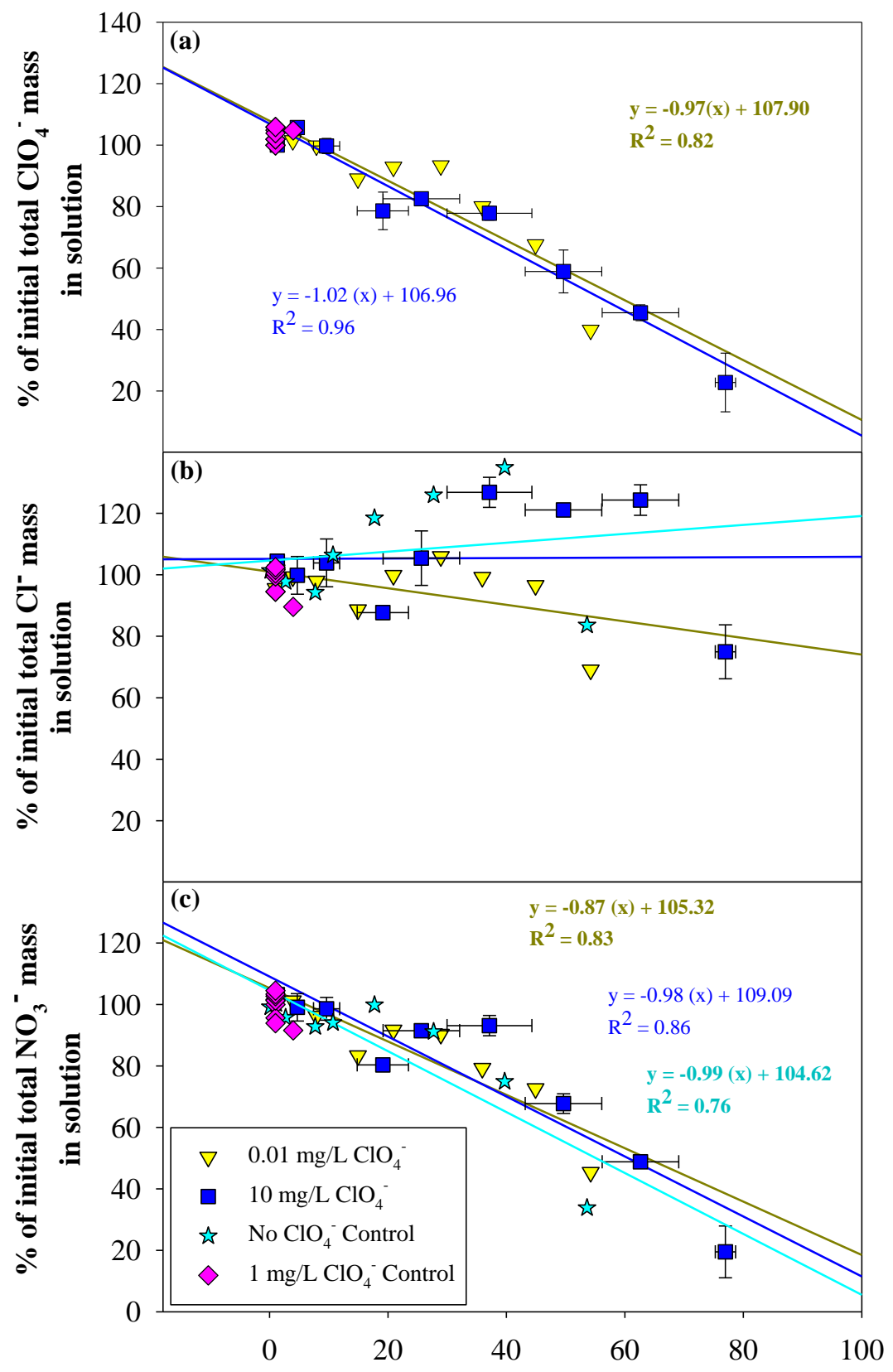

Cumulative Volume of Growth Solution Transpired (L)

Figure 1. Relation between fraction of initial total (a) $\mathrm{ClO}_{4}{ }^{-}$, (b) $\mathrm{Cl}^{-}$, and (c) $\mathrm{NO}_{3}{ }^{-}$mass lost from solution and cumulative volume of solution transpired over the course of experiment 2. Symbols with error bars indicate average values ( \pm standard deviation) for replicated treatments $\left(\mathrm{n}=2\right.$ for 0.01 and $10 \mathrm{mg} / \mathrm{L} \mathrm{ClO}_{4}{ }^{-}$and $\mathrm{n}=1$ for $1 \mathrm{mg} / \mathrm{L}$ and no $\mathrm{ClO}_{4}{ }^{-}$controls). Regressions and associated errors were calculated using the regression wizard function of the Sigmaplot 11 graphing software. The colors of regression lines and regression data are the same as those of the symbols for the treatments they represent (e.g. dark blue $=10 \mathrm{mg} / \mathrm{L} \mathrm{ClO}_{4}{ }^{-}$). Not enough data were collected for a similar analysis of experiment 1 . All $\mathrm{ClO}_{4}{ }^{-}$treatments had plants except the $1 \mathrm{mg} / \mathrm{L} \mathrm{ClO}_{4}{ }^{-}$control. 


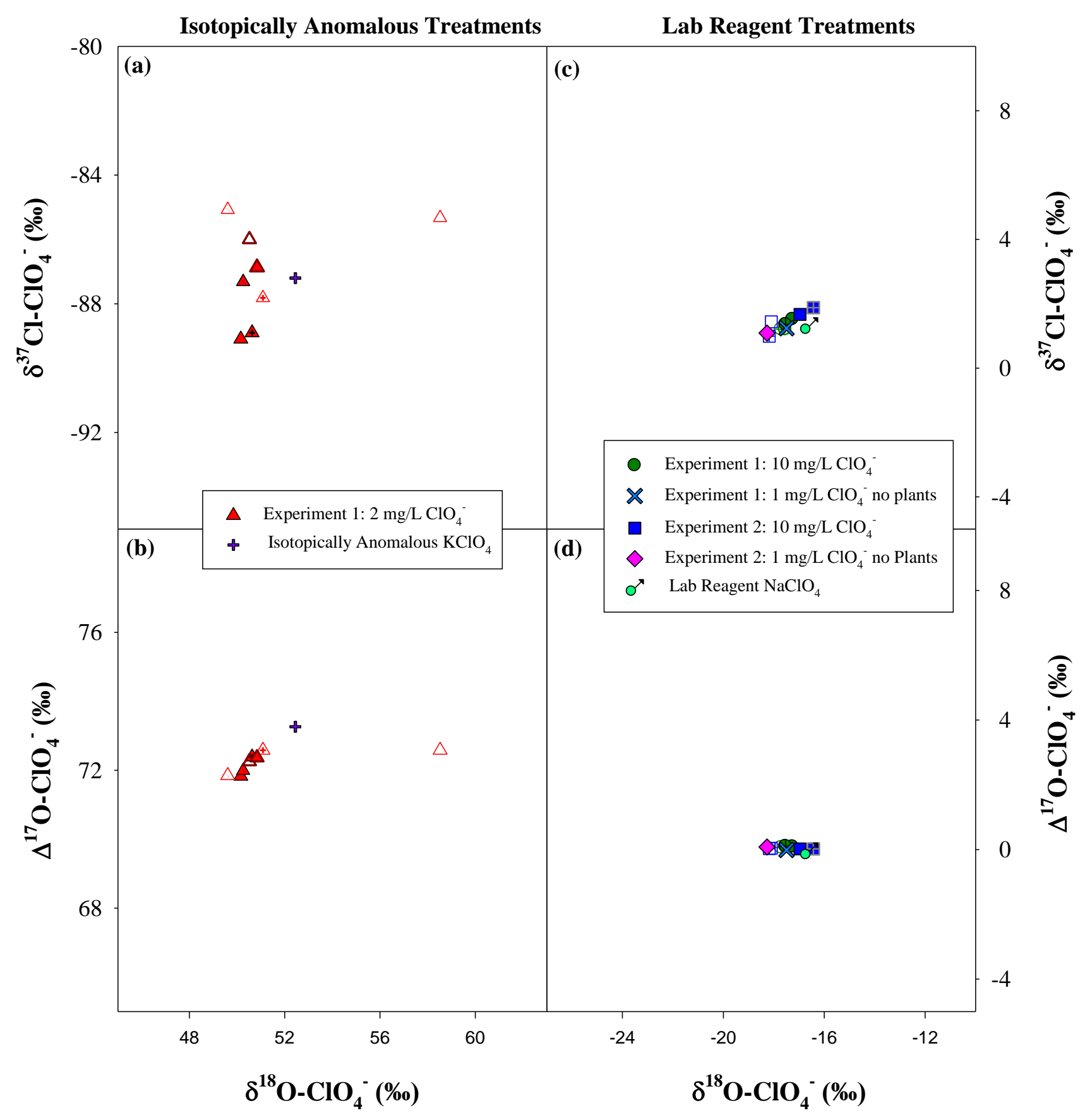

Figure 2. Stable isotopic compositions of $\mathrm{ClO}_{4}{ }^{-}$in nutrient solutions and leaf extracts of all replicate treatments in experiment 1 and 2. Leaf extracts are represented by the open symbols while the final growth solutions are represented by the solid symbols. Experiment 1 replicate treatments are represented by the red triangles $(n=4)$, green circles $(\mathrm{n}=2)$, and light blue cross symbols $(\mathrm{n}=1)$, while experiment 2 replicates are represented by the dark blue squares $(n=2)$ and pink diamond symbols $(n=1)$, where ' $n$ ' equals the number of replicates. $\delta^{37} \mathrm{Cl}, \delta^{18} \mathrm{O}$, and $\Delta^{17} \mathrm{O}$ values are referenced to 0 for Standard Mean Ocean Chloride (SMOC) and Vienna-Standard Mean Ocean Water (VSMOW) international reference standards, respectively. 


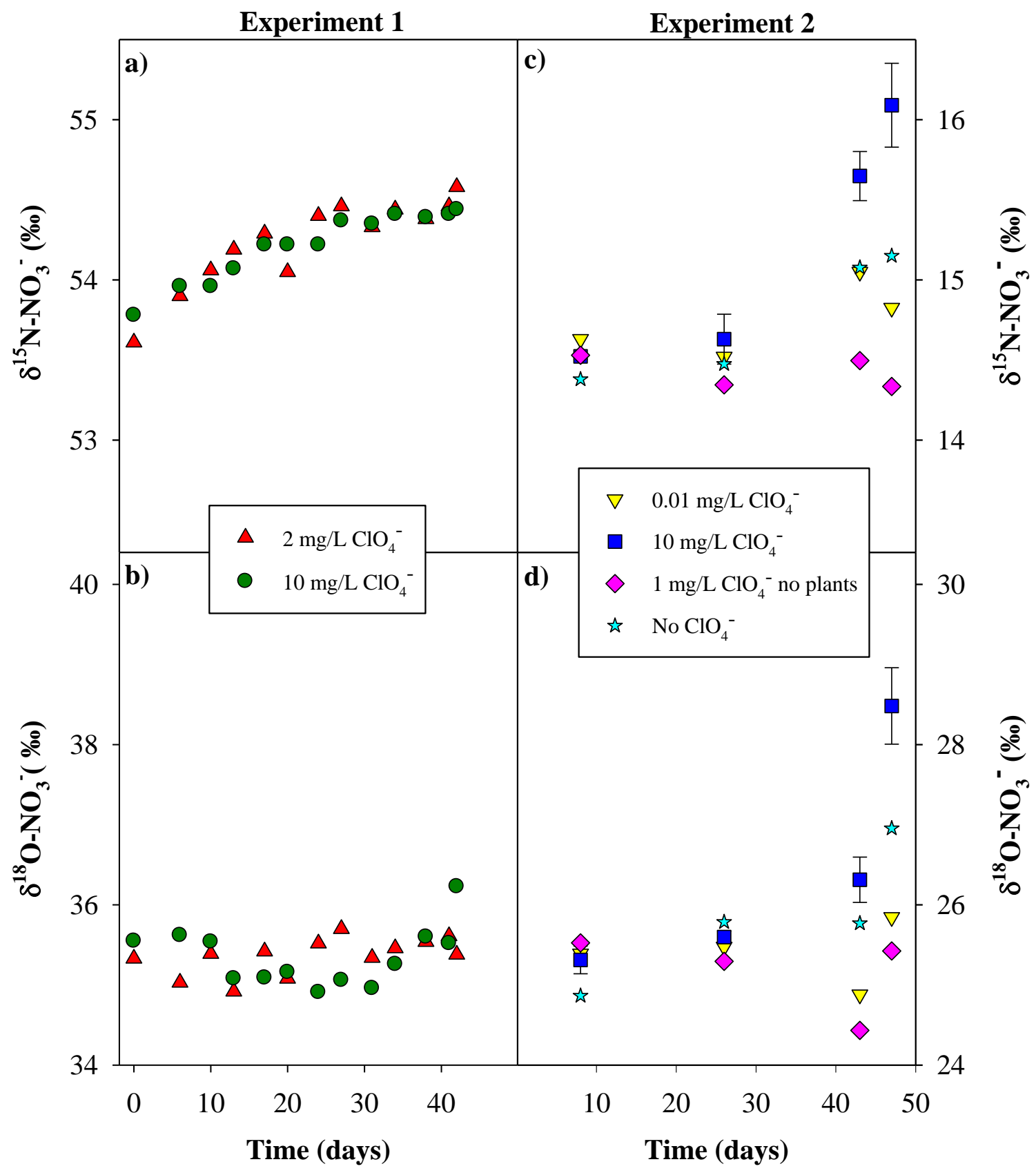

Figure 3. Stable isotopic compositions of $\mathrm{NO}_{3}{ }^{-}$in nutrient growth solutions as a function of time. Symbols with error bars indicate average values $( \pm$ standard deviation) for replicated treatments ( $\mathrm{n}=2$ for 0.01 and $10 \mathrm{mg} / \mathrm{L} \mathrm{ClO}_{4}{ }^{-}$and $\mathrm{n}=1$ for 1 $\mathrm{mg} / \mathrm{L}$ and no $\mathrm{ClO}_{4}{ }^{-}$controls). In experiment 1 the $\mathrm{NO}_{3}{ }^{-}$isotopic compositions of growth solutions in control treatments were not measured and the $\mathrm{NO}_{3}{ }^{-}$isotopic compositions of growth solutions of only one replicate in the 2 and $10 \mathrm{mg} / \mathrm{L} \mathrm{ClO}_{4}{ }^{-}$ treatments were measured. First time point in each experiment represents the $\mathrm{NO}_{3}{ }^{-}$ isotopic composition of initial solution. $\mathrm{All} \mathrm{ClO}_{4}{ }^{-}$treatments had plants except the 1 $\mathrm{mg} / \mathrm{L} \mathrm{ClO}_{4}{ }^{-}$no plants control. 


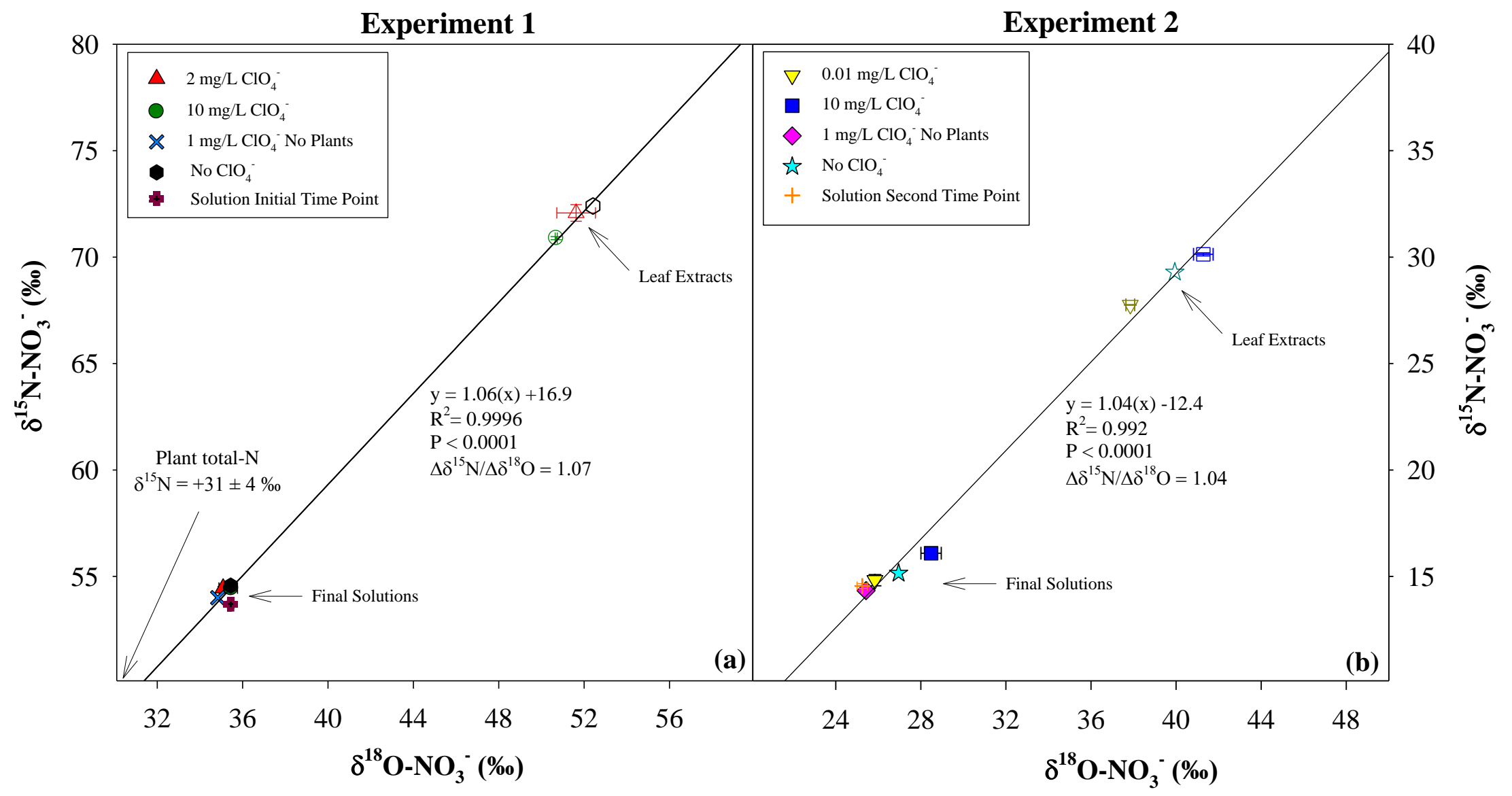

Figure 4. Stable isotopic compositions of $\mathrm{NO}_{3}{ }^{-}$in final growth solutions (solid symbols) and leaf extracts (open symbols) of treatments with plants. Symbols with error bars indicate average values ( \pm standard deviation) for replicated treatments: $\mathrm{n}=4$ for $2 \mathrm{mg} / \mathrm{L} \mathrm{ClO}_{4}^{-}$(experiment 1), $\mathrm{n}=2$ for 0.01 and $10 \mathrm{mg} / \mathrm{L} \mathrm{ClO}_{4}{ }^{-}$(experiment 1 and 2), and $\mathrm{n}=1$ for $1 \mathrm{mg} / \mathrm{L}$ and no $\mathrm{ClO}_{4}{ }^{-}$controls (experiment 1 and 2). Plant total- $\mathrm{N}$ $\delta^{15} \mathrm{~N}$ was only measured in experiment 1 . The regression slope is equal to the $\Delta\left(\delta^{15} \mathrm{~N}: \delta^{18} \mathrm{O}\right)$ ratio. Note that the standard deviations shown are smaller than the symbol size. 


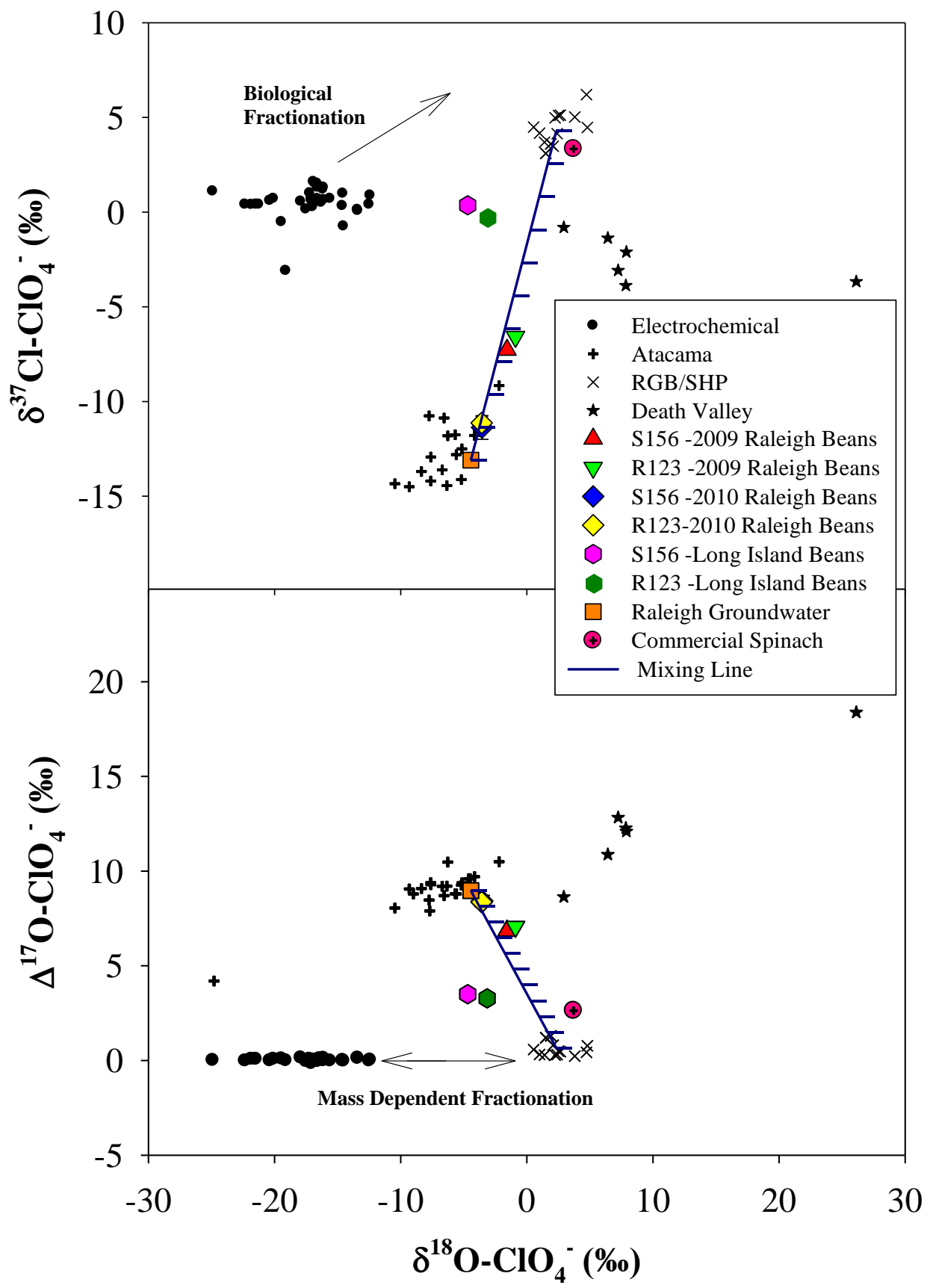

Figure 5. Summary of isotope data for $\mathrm{ClO}_{4}{ }^{-}$from Raleigh, $\mathrm{NC}$ and Long Island, $\mathrm{NY}$ field studies and commercial spinach displayed with previously published $\mathrm{ClO}_{4}{ }^{-}$isotope data from synthetic (electrochemical) and natural sources from the Atacama Desert in Chile, Death Valley (DV), California, and the Southern High Plains (SHP) and Middle Rio Grande Basin (MRGB) of Texas and New Mexico (Jackson et al., 2010; Böhlke et al., 2005). Symbols with error bars for the 2010 Raleigh bean varieties S156 $(n=3)$ and R123 $(n=2)$ indicate average values $( \pm$ standard deviation). The mixing line indicates varying proportions of two end-member $\mathrm{ClO}_{4}$ sources (Raleigh groundwater and natural RGB/SHP-type), with hash lines at 10\% intervals. Symbols for S156-2010 Raleigh Beans are largely masked by those of R123-2010 Raleigh Beans. 